\title{
Triazole analogues as potential pharmacological agents: a brief review
}

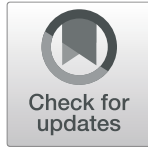

Sachin Kumar ${ }^{*}$ Sukhbir Lal Khokra and Akash Yadav

\begin{abstract}
Background: A large number of studies have recently reported that, because of their significant biological and pharmacological properties, heterocyclic compounds and their derivatives have attracted a strong interest in medicinal chemistry. The triazole nucleus is one of the most important heterocycles which has a feature of natural products as well as medicinal agents. Heterocyclic nitrogen is abundantly present in most medicinal compounds. The derivatization of triazole ring is based on the phenomenon of bio-isosteres in which substituted the oxygen atom of oxadiazole nucleus with nitrogen triazole analogue.

Main text: This review focuses on recent synthetic procedure of triazole moiety, which comprises of various pharmacological activities such as antimicrobial, anticonvulsant, anti-inflammatory, analgesic, antitubercular, anthelmintic, antioxidant, antimalarial, antiviral, etc..

Conclusion: This review highlights the current status of triazole compounds as different multi-target pharmacological activities. From the literature survey, triazole is the most widely used compound in different potential activities.
\end{abstract}

Keywords: Analgesic, Anthelmintic, Anti-inflammatory, Antimicrobial, Triazole

\section{Background}

In the field of research and the synthesis of new bioactive molecule, heterocyclic chemistry plays the most important role. Medicinal chemistry is a part of the medical and pharmaceutical sciences, is concerned with the development and design, and credits the significant biologically active drug molecule. The most active biological activities have been shown among these heterocyclic molecules containing nitrogen and oxygen. Many different compounds have been prepared and exhibit different types of useful pharmacological activity [1].

To investigate a new agent is one of the most difficult tasks for the medicinal chemist. Synthesis of heterocyclic systems consisting high nitrogen has been rising over the past decade owing to their usefulness in different applications such as propellants, explosives, pyrotechnics, and especially chemotherapy. In recent years, considerable attention has been received by the chemistry of

\footnotetext{
* Correspondence: Sethisachin57@gmail.com

Institute of Pharmaceutical Sciences, Kurukshetra University, Kurukshetra, Haryana 136119, India
}

\section{Springer Open}

(c) The Author(s). 2021 Open Access This article is licensed under a Creative Commons Attribution 4.0 International License, which permits use, sharing, adaptation, distribution and reproduction in any medium or format, as long as you give appropriate credit to the original author(s) and the source, provide a link to the Creative Commons licence, and indicate if changes were made. The images or other third party material in this article are included in the article's Creative Commons licence, unless indicated otherwise in a credit line to the material. If material is not included in the article's Creative Commons licence and your intended use is not permitted by statutory regulation or exceeds the permitted use, you will need to obtain permission directly from the copyright holder. To view a copy of this licence, visit http://creativecommons.org/licenses/by/4.0/. triazoles and their fused heterocyclic derivatives because of their synthetic and effective biological importance [2].

Azolic derivatives such as thiazole, triazole, oxadiazole, and thiadiazole are pharmacologically active compounds and, due to their effective use in medicinal chemistry, have been intensely studied for various biological activities [3].

\section{Main text \\ Triazole}

Triazole is a five-member heterocyclic ring containing two carbon and three nitrogen atoms with molecular formula $\mathrm{C}_{2} \mathrm{H}_{3} \mathrm{~N}_{3}$ [4]. And it is found in two isomeric forms, 1,2,3triazole and 1,2,4-triazole, which are also known as pyrrodiazole. (Fig. 1).

Triazoles are white-to-pale yellow crystals with a weak odour, soluble in water and alcohol at a melting point of $120{ }^{\circ} \mathrm{C}$ and $260{ }^{\circ} \mathrm{C}$ [5]. In medicinal chemistry, fivemember heterocyclic nitrogen-containing compounds such as triazole are of great importance due to their wide range of biological applications such as anticonvulsant $[6$, $7]$, antimicrobial [8,9], antiviral [10, 11], antitubercular 
<smiles>c1c[nH]nn1</smiles><smiles>c1cn[nH]n1</smiles><smiles>c1nc[nH]n1</smiles><smiles>c1nnc[nH]1</smiles>

\section{H-1,2,3-triazole $2 H$-1,2,3-triazole $1 H$-1,2,4-triazole $4 H$-1,2,4-triazole}

\section{1,2,3-triazole}

\section{1,2,4-triazole}

Fig. 1 Different isomeric forms of triazole

[12], antidiabetic [13], anti-inflammatory [14, 15], antiproliferative [16-18], antioxidant [19], anti-urease [19], and antimalarial activities [20, 21]. (Fig. 2).

\section{Synthetic approaches of triazoles}

The article gives a brief review of the synthetic procedure and characterization of triazole and its pharmacological activity.

Lu yang et al. reported 4-acyl-NH-1,2,3-triazole synthesis by the use of water-mediated cycloaddition reactions of enaminone and tosilazide, requiring both a mild condition $\left(40{ }^{\circ} \mathrm{C}\right)$ and practical scalability, when using the water as sole medium without any catalyst (Scheme 1) [22].

Shelke et al. had synthesized and found that, in the absence of a catalyst, the substitution of 1,2,4 triazole from hydrazine and formamide under microwave irradiation and this reaction effectively indicates excellent functional group tolerance (Scheme 2) [23].
Bechara et al. reported the synthesis of 3,4,5-Trisubstituted 1,2,4-triazole from $2^{\circ}$ amides and hydrazides by triflic anhydride activation followed by the microwave cyclodehydrationto be1,2,4-Triazole moiety is a useful leading group of Ru-catalyzed C-H arylation (Scheme 3) [24].

Yin et al. synthesized a substituted triazole by one pot cyanoimidation of aldehydes where cyanamide as nitrogen source and the NBS as an oxidant in high yield without any catalyst. The substituted product N-cyanobenzimidate may also be subjected to a cyclization reaction to produce a high yield of 1,2,4-triazole derivative (Scheme 4) [25].

Faldiman et al. reported 1,4 disubstituted 1,2,3 triazoles from azides. These are obtained with excellent yield from aromatic and aliphatic halides that are easily available without formation of potentially unstable organic azide intermediates (Scheme 5) [26].

Liu et al. reported a novel substituted 3,5-diamine-1,2,4triazole from isothiocynate and mono-substituted hydrazines and sodium hydrogen cyanamide (Scheme 6) [27].

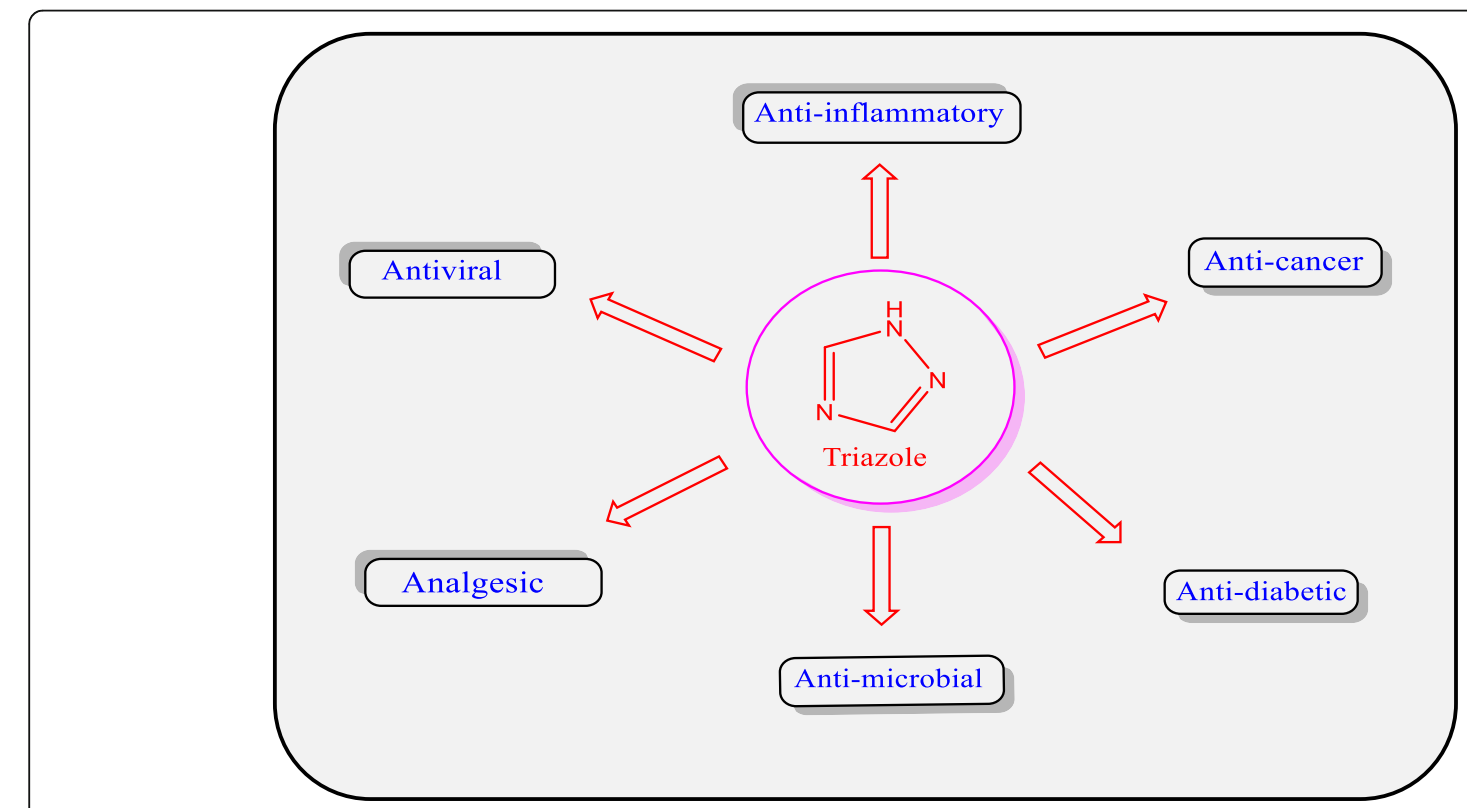

Fig. 2 Significant biological activities of triazole derivatives 


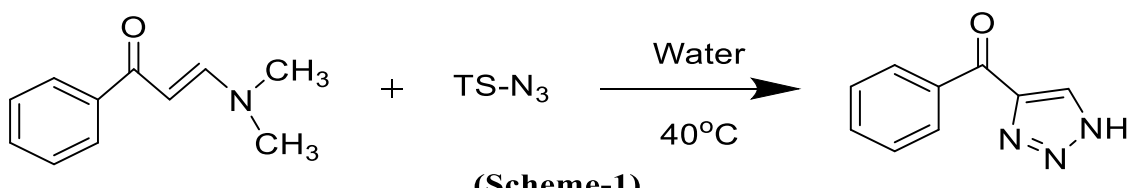

(Scheme-1)

Scheme 1 Synthesis of 4-acyl-NH-1,2,3-triazole

$$
\mathrm{R}-\mathrm{NHNH}_{2}+\prod_{\mathrm{H}}^{\mathrm{O}} \mathrm{NH}_{2} \longrightarrow \mathrm{MW(230 \textrm {w } , 1 7 \mathrm { atm } ) , 1 6 0 ^ { \circ } \mathrm { C } , 1 0 \mathrm { atm }} \longrightarrow
$$

(Scheme-2)

Scheme 2 Synthesis with substitution of 1,2,4 triazole from hydrazine and formamide

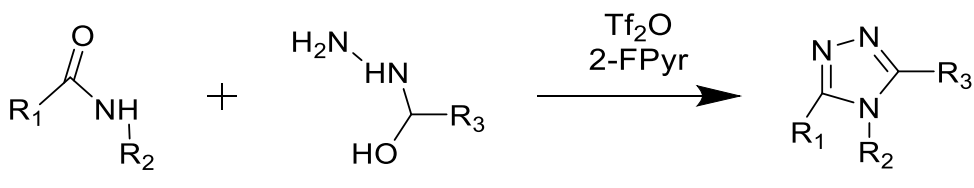

(Scheme-3)

Scheme 3 Synthesis of 3,4,5-Trisubstituted 1,2,4-triazole from 2 amides and hydrazides

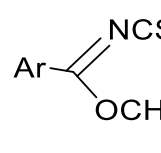

$+\mathrm{PhNHNH}_{2}$

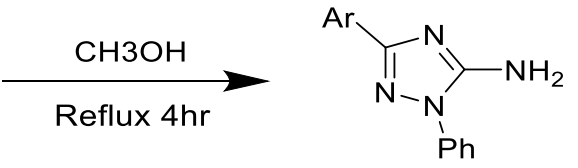

(Scheme-4)

Scheme 4 Synthesis of a substituted triazole by one pot cyanoimidation of aldehydes 


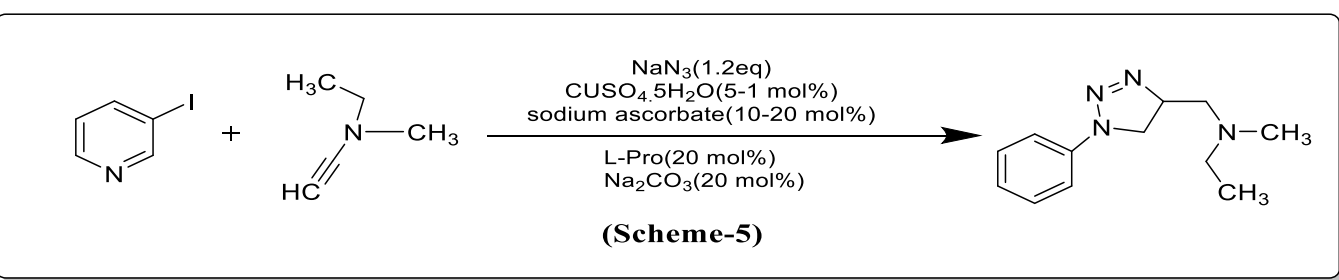

Scheme 5 1,4 Disubstituted 1,2,3 triazoles from azides

Zhengkaichen et al. reported a metal-free synthesis of 1,3, 5-trisubstituted-1,2,4-triazoles in the presence of iodine as catalyst (Scheme 7). And it can be synthesized from hydrazones and aliphatic amines under oxidative conditions via a cascade $\mathrm{C}-\mathrm{H}$ functionalization, double $\mathrm{C}-\mathrm{N}$ bond formation, and oxidative aromatization [28].

\section{Pharmacological activities of triazole derivatives}

This article presented discusses a brief description of the various triazole activities, and the recent studies have showed the wide range of pharmacological activities available for triazole derivatives which may be divided into the following categories:

\section{Antimicrobial activity}

Fabrice et al. synthesized a novel series of 1,2,4-triazole-indole hybrids and evaluated their antifungal activity. All the synthesized hybrids were characterized by IR, NMR, and mass and elemental spectroscopy. The compound (2-(2,4Dichlorophenyl)-3-(1H-indol-1-yl)-1-(1,2,4-1H-triazol-1-yl) propan-2-ol 1a exhibited the excellent activity against Candida, particularly against low fluconazole susceptible species. Result showed that this compound exhibited high activity as compared with fluconazole and similar to voriconazole against C. glabrata, C. krusei, and C. albicans [29].

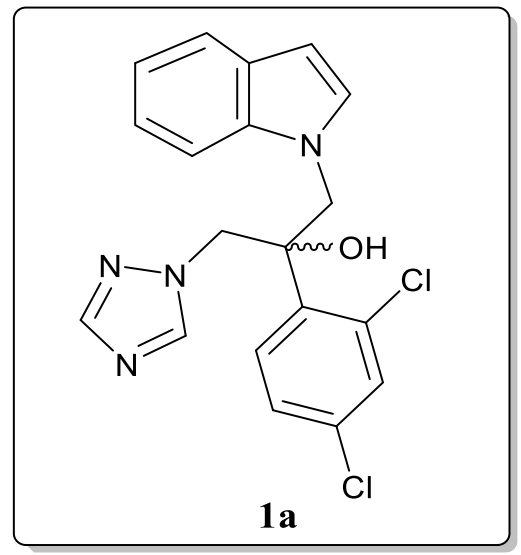

Wujec et al. synthesized the ten compounds which contain the manic base-1,2,4 triazole. The broth microdilution technique was used against Grampositive and Gram-negative bacteria to evaluate antimicrobial activity of these compounds. The phenyl ring present in the 4-position of piperazine appears essential for antibacterial action. Compound 2a showed the potent activity with MIC value $30 \mu \mathrm{g} / \mathrm{mL}$ against $M$. luteus and $60 \mu \mathrm{g} / \mathrm{mL}$ against three different bacterial strains (B. subtilis, S. aureus, and S. epidermidis) [30].

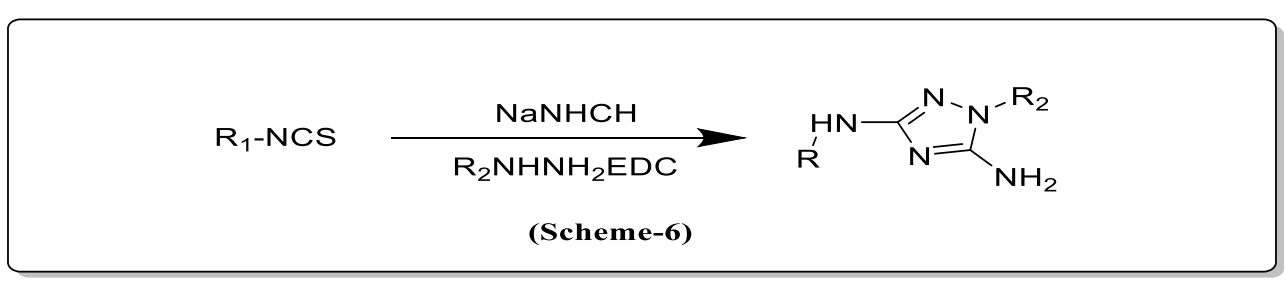

Scheme 6 Novel substituted 3,5-diamine-1,2,4-triazole 


$$
\mathrm{Ar}^{-\mathrm{N}} \mathrm{N}=\mathrm{R}_{\mathrm{R}+} \sum_{\substack{\mathrm{MeCN}, \text { air } \\ 90^{\circ} \mathrm{C}, 4 \mathrm{hr}}}^{\mathrm{NBH}}
$$

Scheme 7 Metal-free synthesis of 1,3,5-trisubstituted-1,2,4-triazoles in the presence of iodine as catalyst

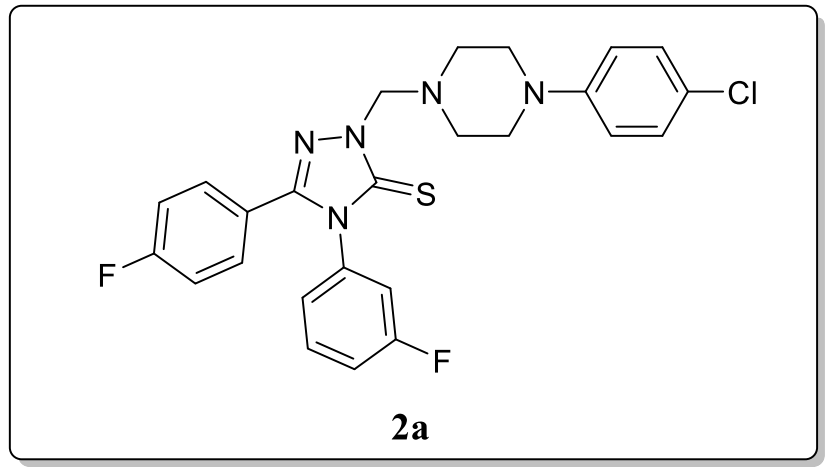

Lipeeva et al. synthesized and investigated a novel series of 1,2,3-triazole-substituted coumarins and tested their in vitro antimicrobial activity against four different bacterial strains. Result showed that compounds $\mathbf{3 a}, \mathbf{3 b}$, and $\mathbf{3} \mathbf{c}$ showed potent activity against $S$. aureus strains with MIC values ranging between 0.16 and $0.41 \mu \mathrm{g} / \mathrm{mL}$ as compared with the reference drug ceftriaxone and streptomycin. The structure activity relationship of compound (carboxamidotriazolylbenzoic acid) substitution at position C-6 of coumarin core displayed promising activity towards $A$. viscosus as compared with compound $\mathbf{3} \mathbf{b}$. The compound $\mathbf{3 b}$ with triazolylbenzoic acid substitute in the $\mathrm{C}-7$ position exhibited highest activity towards the bacterial strains of S. aureus "Viotko", and compound 3c with the substitution of 3-ethynylcoumarin with methylanthranilate exhibited remarkable antibacterial activity against the strains of S. aureus [31].
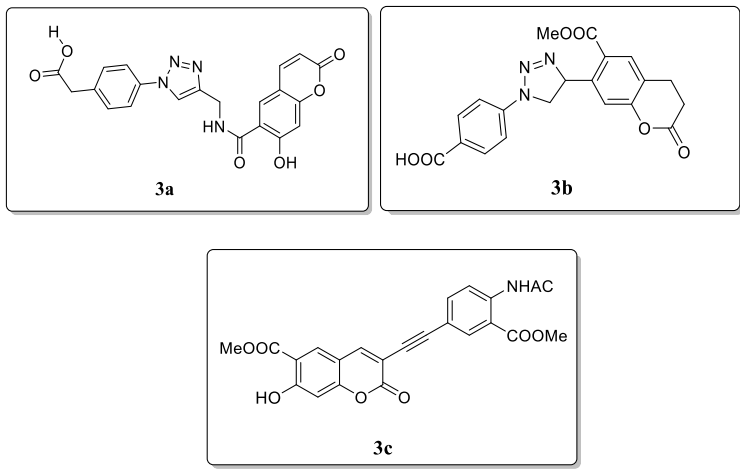

Tang et al. synthesized the triazolyl-pterostilbene derivatives, and their antimicrobial activity was evaluated. Among all these compounds, compound 4a showed the most potent antimicrobial activity with MIC values of $1.2-2.4 \mu \mathrm{g} / \mathrm{mL}$ and $\mathrm{MBC}$ values of $19.5-39 \mu \mathrm{g} / \mathrm{mL}$. On the other hand, structural activity analysis showed introduction of the phenyl group as a spacer on compound $\mathbf{4 a}$ exhibited significant antimicrobial activity [32].

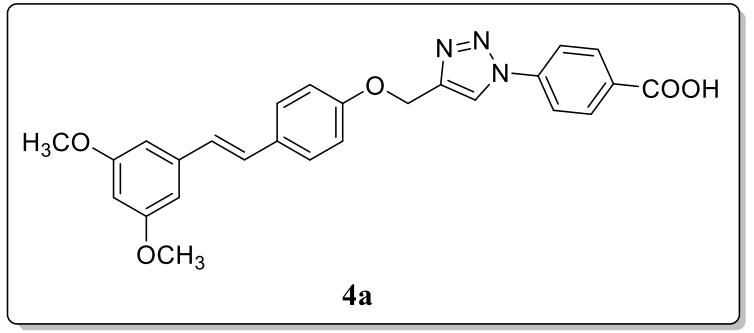

Tingjunhong Ni et al. synthesized twenty-seven triazole derivatives containing alkynyl side chains, and their antifungal activity towards Cryptococcus and Candida species were evaluated as compared with reference drugs. The results showed that the compounds $\mathbf{5 a}$ and $\mathbf{5 b}$ demonstrated in vitro activity towards all fungi with $\mathrm{MIC}_{80}$ values in range between 0.0156 and $0.5 \mu \mathrm{g} / \mathrm{mL}$, higher than ravuconazole and fluconazole. Structural relationships showed the introduction of fluoro, chloro, and cyano groups at p-position of phenyl alkynyl or pyridinyl alkynyl side chain enhances their antifungal activity [33].
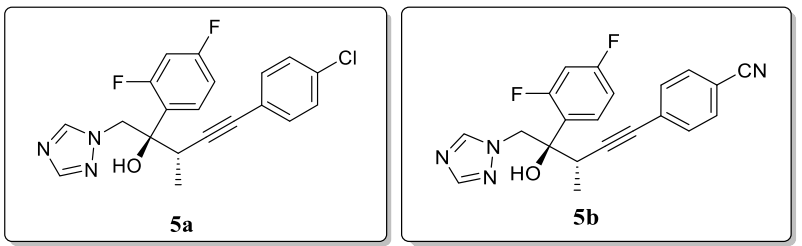

Yang et al. synthesized the derivatives of quinazoline (E)-2-(4-(1H-1,2,4-triazol1-yl) as an antimicrobial agent. Among these compounds, in vitro antimicrobial activity was evaluated against three phytophatogenic bacteria (Xac, Xoo, and Rs) as compared with the reference bismerthiazole (BMT) drug. Among them, compounds 6a, 
6b, and 6c showed better antibacterial activity against pathogen $\mathrm{Xac}$ and its $\mathrm{EC}_{50}$ values are 53.2, 67.7, and 70.7 $\mu \mathrm{g} / \mathrm{mL}$. And the antifungal activity also evaluated against the three phytopathogenic fungi. Result revealed that the compounds $\mathbf{6 c}, \mathbf{6 d}, \mathbf{6 e}$, and $\mathbf{6 f}$ showed the modest inhibition activities with $\mathrm{EC}_{50}$ values $45.7 \pm 1.8,40.7 \pm 2.1$, 43.6 \pm 1.7 , and $43.1 \pm 2.1$ respectively against $S$. sclerotiorum with the reference of Hymexazol at $50 \mu \mathrm{g} / \mathrm{mL}$, having > $40 \%$ inhibition rate [34] where value of $\mathrm{R}$ in $6 \mathrm{a}$. $\mathrm{R}=$ $\mathrm{C}(\mathrm{CH} 3) 3 \mathrm{C} 6 \mathrm{H} 4,6 \mathrm{~b} . \mathrm{R}=2,6-\mathrm{Cl} 2 \mathrm{C} 6 \mathrm{H} 3,6 \mathrm{c} . \mathrm{R}=4-\mathrm{FC} 6 \mathrm{H} 4$, 6d. $\mathrm{R}=\mathrm{CH} 3,6 \mathrm{e} \cdot \mathrm{R}=(\mathrm{CH} 2) 2 \mathrm{CH} 3,6 \mathrm{f} .=\mathrm{C} 6 \mathrm{H} 5$.

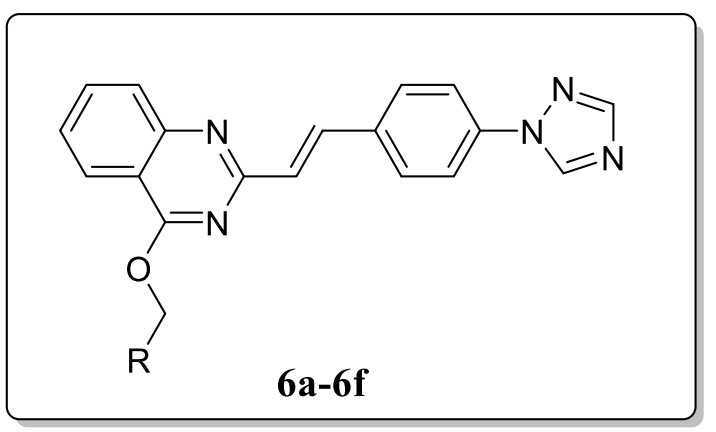

Rezki et al. reported and investigated a novel series of 2,5-disubstituted thiadiazole clubbed 1,2,4-triazole as a potential antimicrobial agent. All derivatives were characterized by IR, ${ }^{1} \mathrm{H}-\mathrm{NMR},{ }^{13} \mathrm{C}-\mathrm{NMR}, \mathrm{MS}$, and elemental analysis. In vitro inhibitory growth activities of three Gram-positive (+) bacteria, three Gramnegative (-) fungi, and three strains of normal pathogenic microorganism strains were tested of all these compounds. SAR studies revealed the presence of phenyl or alkyl substitution at N-4 has enhanced their antimicrobial activity towards strains of bacteria and fungi with MIC values of $8-16 \mu \mathrm{g} / \mathrm{mL}$, where ciprofloxacin and fluconazole are the reference drugs (Table 1). Compounds $7 \mathbf{a}-7 \mathbf{c}$ were found to be the most potent antimicrobial agent [35].

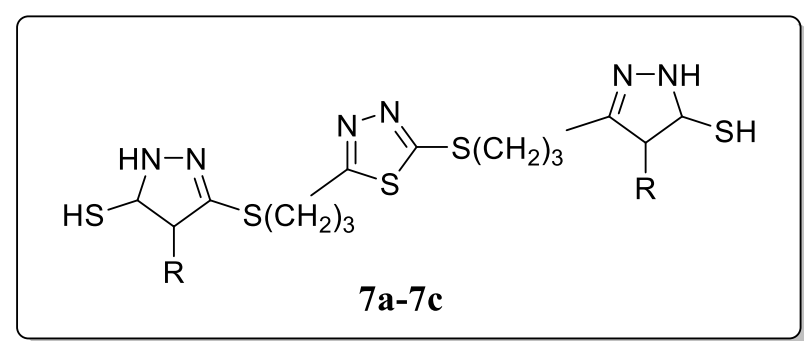

$$
\mathbf{7 a}=\mathrm{C}_{6} \mathrm{H}_{5} \quad \mathbf{7 b}=\mathrm{CH}_{3} \quad \mathbf{7} \mathbf{c}=\mathrm{CH}_{2} \mathrm{CH}_{3}
$$

Tijenonkol et al. reported the 3-[1(2H)-phthalazinone-2yl(substituted)-4-aryl-1,2,4-triazole-5-thione derivatives and evaluated their antibacterial activity and screened them against Gram (+) \& Gram (-) bacterial strains and fungal strains by using the broth microdilution method. Result revealed that the compounds $\mathbf{8 a}-\mathbf{8 e}$ exhibited the antibacterial activity is $25 \%$ against B. subtilis. And the antifungal activity of compound $8 \mathbf{c}$ was found to be $25 \%$ against $C$. albicans. The MIC value of compound $8 \mathbf{e}$ towards C. albicans and C. parapsilosis was $64 \mu \mathrm{g} / \mathrm{mL} \& 32 \mu \mathrm{g} / \mathrm{mL}$, and compound 8d was active towards $C$. parapsilosis with MIC value $32 \mu \mathrm{g} / \mathrm{mL}$ (Table 2) [36].

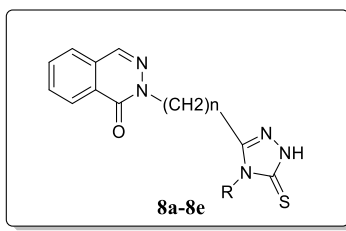

\begin{tabular}{|c|c|c|}
\hline Comp. & N & R \\
\hline $\mathbf{8 a}$ & 1 & Benzyl \\
\hline $\mathbf{8 b}$ & 1 & Phenethyl \\
\hline $\mathbf{8 c}$ & 1 & $4-$ methoxyphenyl \\
\hline $\mathbf{8 d}$ & 2 & Phenethyl \\
\hline $\mathbf{8 e}$ & 2 & 4-methoxyphenyl \\
\hline
\end{tabular}

Turan-Zitouni et al. synthesized 4-phenyl-cyclohexyl5-(1-phenoxyethyl)-3-[N-(2-thiazolyl)acetamido] thio-4H1,2,4-triazole analogues and tested their antimicrobial activity. Among these synthesized compounds, only compound 9a showed excellent antifungal activity [37].

Table 1 Antimicrobial activity expressed as MIC $(\mu \mathrm{g} / \mathrm{mL})$

\begin{tabular}{|c|c|c|c|c|c|c|c|c|c|}
\hline \multirow[t]{2}{*}{ Comp. } & \multicolumn{3}{|c|}{ Gram positive } & \multicolumn{3}{|c|}{ Gram negative } & \multicolumn{3}{|c|}{ Fungi } \\
\hline & $S p$ & Bs & Sa & $\mathrm{Pa}$ & $E c$ & $K p$ & $A f$ & $\mathrm{Ca}$ & Gc \\
\hline $7 a$ & 8 & 8 & 16 & 16 & 16 & 16 & 8 & 8 & 16 \\
\hline $7 b$ & 16 & 31.5 & 16 & 31.5 & 31.5 & 8 & 16 & 16 & 31.5 \\
\hline 7c & 16 & 16 & 8 & 31.5 & 16 & 16 & 16 & 31.5 & 16 \\
\hline Ciprofloxacin & $<5$ & $<1$ & $<5$ & $<5$ & $<1$ & $<1$ & - & - & - \\
\hline Fluconazole & - & - & - & - & - & - & $<1$ & $<1$ & $<1$ \\
\hline
\end{tabular}


Table 2 Minimum inhibition of concentration compound ( $\mu \mathrm{g} / \mathrm{mL})$

\begin{tabular}{|c|c|c|c|c|c|c|}
\hline Comp. & S. aureus & B. subtilis & E. coli & P. aeruginosa & C. albicans & C. parapsilosis \\
\hline $8 a$ & 512 & $32^{*}$ & 256 & 256 & 128 & 64 \\
\hline $8 b$ & 256 & 256 & 128 & 256 & $32^{*}$ & $32^{*}$ \\
\hline $8 c$ & 512 & $32^{*}$ & 256 & 256 & 512 & 512 \\
\hline $8 d$ & 512 & $32^{*}$ & 256 & 256 & $64^{*}$ & $32^{*}$ \\
\hline $8 e$ & 512 & 64 & 256 & 256 & 64 & $32 *$ \\
\hline
\end{tabular}

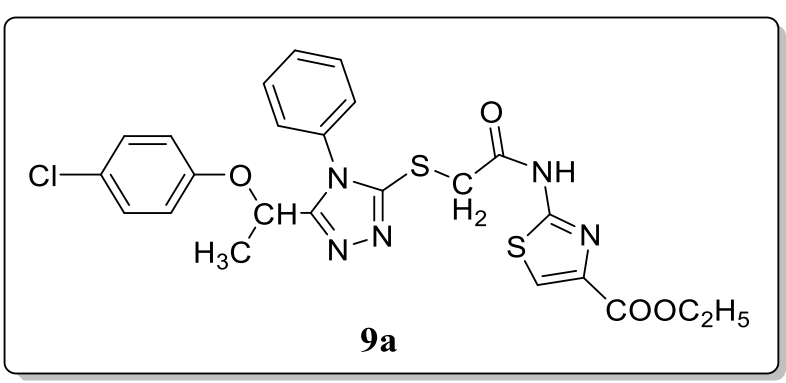

Hussain et al. synthesized eleven 1,4-disubstituted1,2,3-triazole derivatives for antibacterial activity. All the synthesized derivatives were characterized spectroscopically, and their activities were evaluated. And the preliminary results of the synthesized derivatives showed the high inhibitory effects compared with the control ciprofloxacin. Result showed that the compounds 10a and 10b were found to be potent (MIC: $5 \mu \mathrm{g} / \mathrm{mL}$, MIC: $10 \mu \mathrm{g} / \mathrm{mL}$ respectively) antibacterials against various strains of bacteria. And the docking studies showed that the most potent is compound 10a, exhibiting high binding energy and inhibition constant [38].
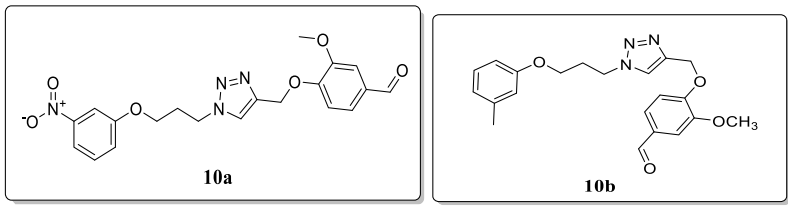

Han et al. reported a new series of triazole derivatives containing different ester skeletons and evaluated as antifungal agents. The antifungal activity was investigated by utilizing the microdilution broth method. In all the synthesized compounds, compounds 11a and 11b showed the most significant activity against four important fungal pathogens $\left(\mathrm{MIC}_{80}=2-8 \mu \mathrm{g} / \mathrm{mL}\right)$. Molecular docking studied revealed the target compounds interact with CYP51 mostly by Van der Waals and hydrophobic interactions [39].
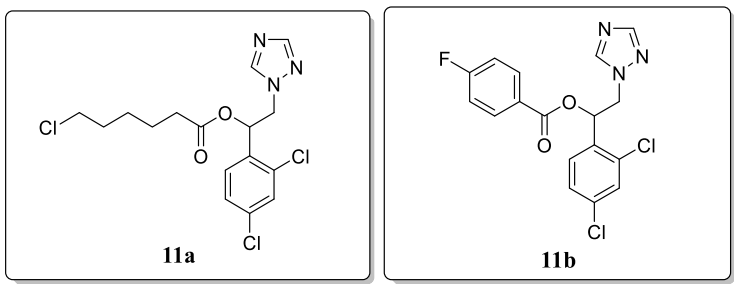

Al-blewi et al. synthesized a novel series 1,4-disubstituted-1,2,3-triazole-sulfonamide hybrids and evaluated for their antimicrobial activity. All the synthesized hybrids were verified by mean of spectroscopic analysis. From the result, only compound 12a showed the most significant activity with MIC value range between 32 and $64 \mu \mathrm{g} / \mathrm{mL}$ as compared with the standard drug [40].

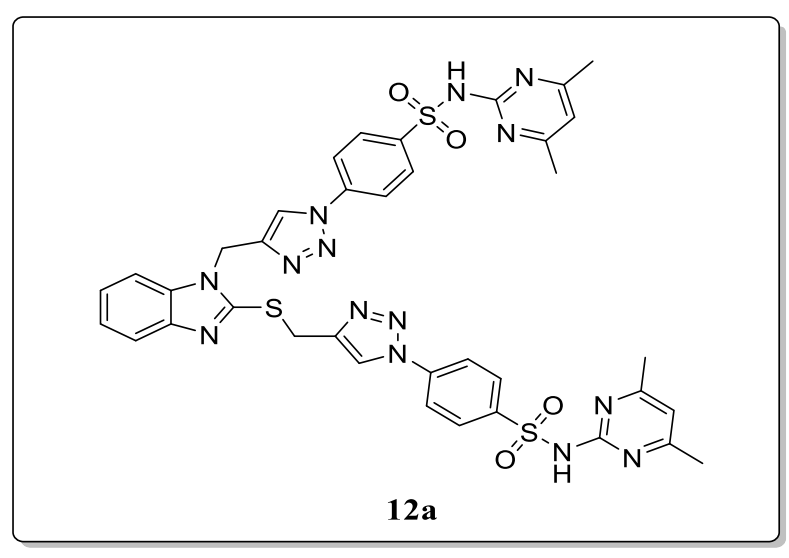

\section{Antitubercular activity}

Ramprasad et al. reported nineteen derivatives of quinoline-triazole hybrids and screened their antitubercular activity against Mycobacterium bovis. Result revealed that two derivatives, 13a and 13b, showed the potent antitubercular activity with MIC values $31.5 \mu \mathrm{m}$ and $34.8 \mu \mathrm{m}$. SAR studies revealed that these compounds are essential for their activity due to n-octyl and 3-fluorophenyl groups presented on 1,2,3-triazole ring [41]. 


\begin{tabular}{|c|c|}
\hline Comp. & $\mathbf{R}$ \\
\hline $13 a$ & \\
\hline $13 b$ & $\left(\mathrm{H}_{2} \mathrm{C}\right) \approx$ \\
\hline
\end{tabular}

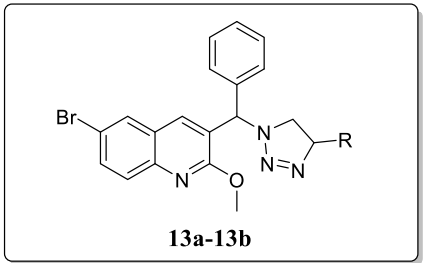

A novel series of triazole-imidazo[2,1-b][1,3,4] thiadiazole hybrids and evaluated their antimycobacterial activity against Mycobacterium tuberculosis H37Rv strain reported by Rampprasad et al.. From the result, two derivatives 14a and 14b demonstrated potent growth inhibition towards the bacterial strain with significant MIC value $3.125 \mu \mathrm{g} / \mathrm{mL}$. Substitution of the ethyl benzyl group on 1,2,3-triazole ring enhances the inhibition activity [42].

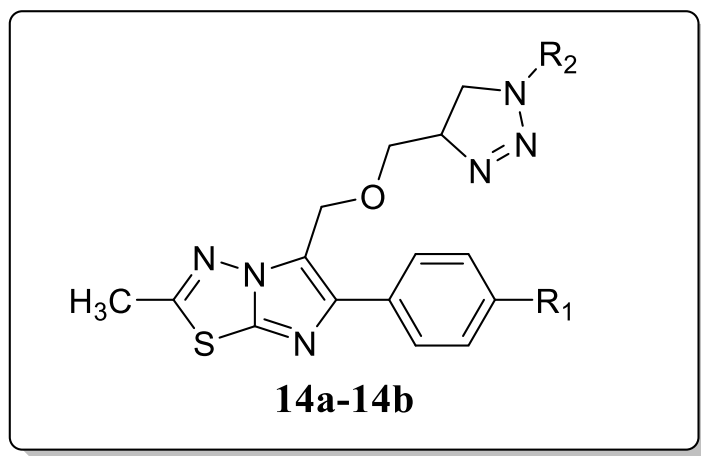

$$
\begin{array}{ll}
\mathbf{1 4 a}=\mathrm{R}_{1}=\mathrm{OCH}_{3} & \mathrm{R}_{2}=\mathrm{CH}_{2}-\mathrm{C}_{6} \mathrm{H}_{5} \\
\mathbf{1 4 b}=\mathrm{R}_{1}=\mathrm{CL} & \mathrm{R}_{2}=\mathrm{CH}_{2} \mathrm{CH}_{3}
\end{array}
$$

Raju et al. synthesized 1H-pyrrolo[2,3-d]pyrimidine-1,2,3-triazole derivatives for in vitro antimycobacterial activity against Mycobacterium tuberculosis H37Rv strain. All synthesized hybrids exhibited significant antitubercular activity. Among these series, compounds 15a and 15b showed the remarkable MIC value $0.78 \mu \mathrm{g} / \mathrm{mL}$. The molecular docking results to the exhibition of high Moldock score of these compounds. SAR studies showed that the triazole ring substituted with heteroaryl compound containing highly electronegative atoms also enhance their activity [43].
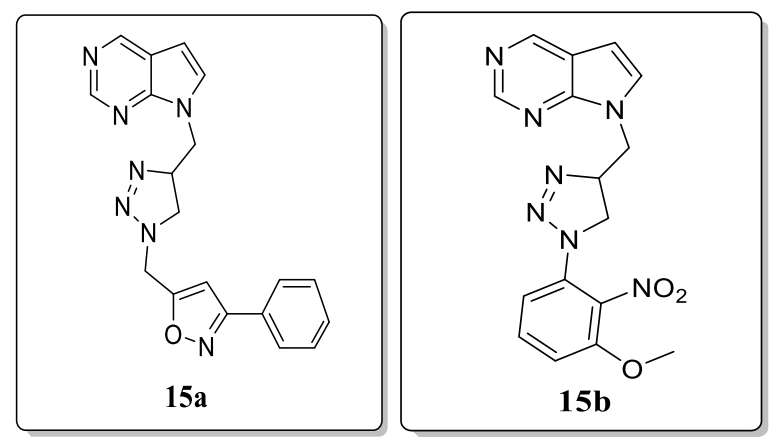

Patela et al. reported a series of N-Mannich base of 1,2, 4-triazole derivatives. All the synthesized derivatives were characterized by spectral and elemental analysis and were screened for in vitro antitubercular activity against $M$. tuberculosis. From the result, in the primary screening, compound 16a revealed the remarkable activity $(\mathrm{MIC}=6.25$ $\mu \mathrm{M})$ against $M$. tuberculosis. The computational studies showed a high affinity towards the active enzyme site for that Mannich derivative 16a that provides a strong platform for new structure-based design efforts [44].

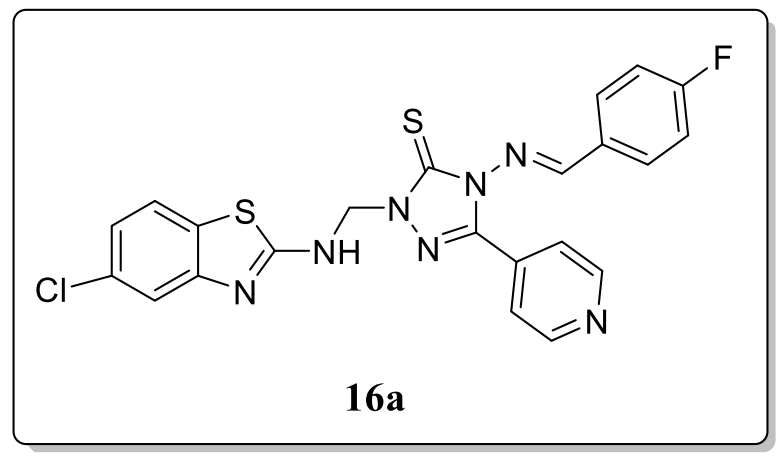

Ali et al. reported and investigated seventeen new 1,2,3-triazole derivatives against Mycobacterium tuberculosis H37Ra (ATCC 25177 strain). The synthesized compounds were characterized by thin-layer chromatography (TLC), ${ }^{1} \mathrm{H}$ NMR, ${ }^{13} \mathrm{C}$ NMR, FT-IR, and mass spectrometry. Among the tested series, compound 17a substituted with the fluoro group at second position on the phenyl ring of the triazole derivatives demonstrated higher anti-mycobacterial activity with $\mathrm{MIC}=0.78 \mu \mathrm{g} / \mathrm{mL}$ as compared with the first-line antitubercular drug ethambutol $(\mathrm{MIC}=2.00 \mu \mathrm{g} / \mathrm{mL})$. However, the compound $\mathbf{1 7 b}$ with the ester group also showed 
significant activity ( $\mathrm{MIC}=1.56 \mu \mathrm{g} / \mathrm{mL}$ ), in contrast with its antimicrobial activity [45].
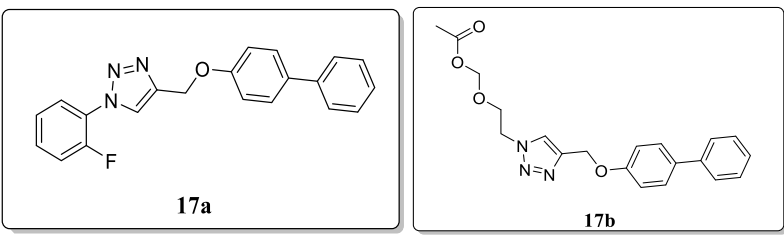

\section{Anthelmintic activity}

Kharb et al. investigated fifteen novel imidazolecontaining triazole derivatives and screened their anthelmintic activity towards Pheretimaposthuma at concentrations of $0.150 \%$ and $0.300 \% \mathrm{w} / \mathrm{v}$ respectively as compared with the albendazole as positive control. Result revealed that, the compound 18a displayed significant anthelmintic activity as compared with the reference drug [46].

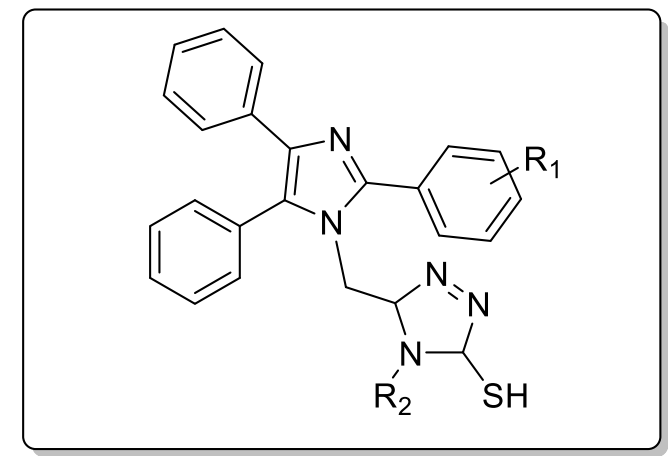

$$
\mathbf{1 8} \mathbf{a}=\mathrm{R}_{1}=4-\mathrm{NO}_{2} \quad \mathrm{R}_{2}=4-\mathrm{CL}-\mathrm{C}_{6} \mathrm{H}_{4}
$$

Gupta et al. reported five derivatives and evaluated for their anthelmintic activity against $P$. posthuma. From the result, compound 19a showed the potent vermicidal activity, and it exhibited the maximum paralysis time and $37.33 \mathrm{~min}$ of death time at $20 \mathrm{mg} / \mathrm{mL}$ concentration $[47,48]$.

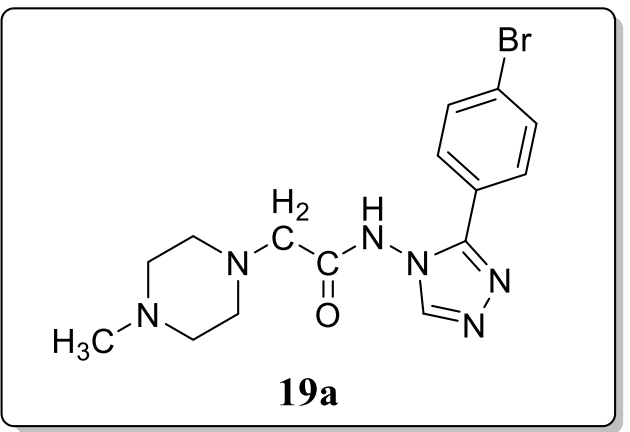

Satyendra et al. synthesized novel di-chloro substituted benzoxazole-triazolo-thione derivatives, and their anthelmintic activities were evaluated. Among them, the compound 20a exhibited the potent anthelmintic activity against $P$. posthuma as compared with the reference albendazole at $1 \%$ concentration [49].

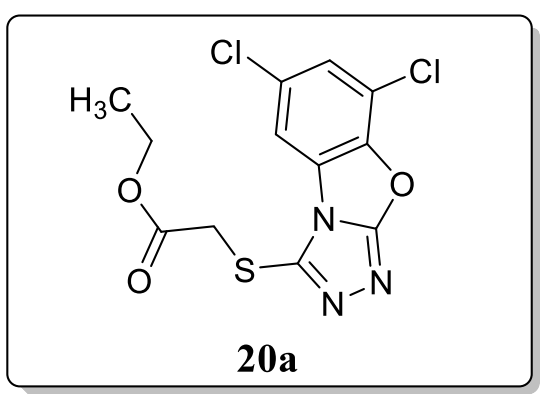

\section{Anticonvulsant activity}

Verma et al. reported a series of novel 4,5-disubstituted-2,4dihydro-3H-1,2,4-triazole-3-thione derivatives for anticonvulsant activity. Anticonvulsant activity of compound wastes by maximal electroshock (MES), subcutaneous pentylenetetrazol (scPTZ) test in mice and rat and neurotoxicity screened at 30,100 , and $300 \mathrm{mg} / \mathrm{kg}$ dose and was suspended in 30\% PEG 400 by an oral route to the mice. Among all these compounds, only compound 21a exhibited significant anticonvulsant activity at $300 \mathrm{mg} / \mathrm{kg}$ at a 4-h duration [50].

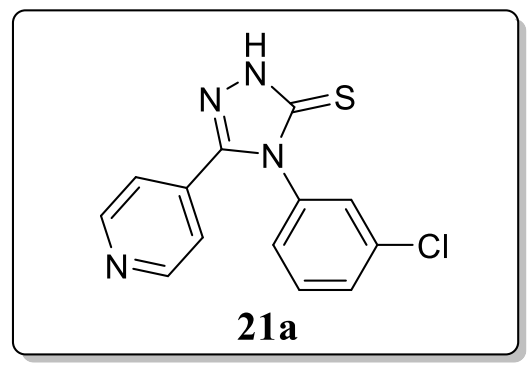

Wang et al. reported a novel series of triazolecontaining 7-phenyl-4,5,6,7-tetrahydrothieno[3,2-b]-pyridine derivatives and screened their anticonvulsant activity. From the result, compound 22a exhibited the potent anticonvulsant activity. Out of the therapeutic index (PI) values, compound 22a displayed better safety profile than carbamazepine and ethosuximide [51].

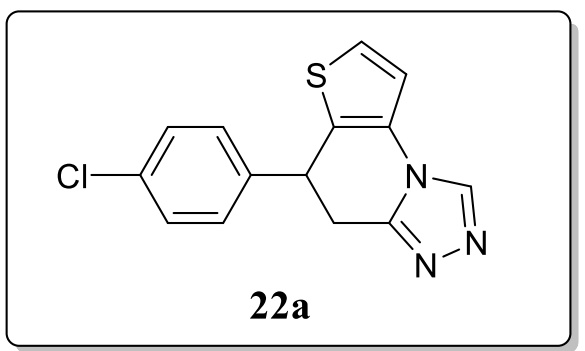


Zhang et al. synthesized a new series 3,4-dihydroisoquinolin containing 1,2,3-triazole compounds and investigated their anti-epileptic activity by using MES (maximal electroshock) and PTZ (pentylenetetrazole)induced seizure test. Among the synthesized compound, only compound 23a showed excellent antiepileptic activity with $\mathrm{ED}_{50}$ value $48.19 \mathrm{mg} / \mathrm{kg}$. It was found to be more active than valproate but less active than carbamazepine [52].

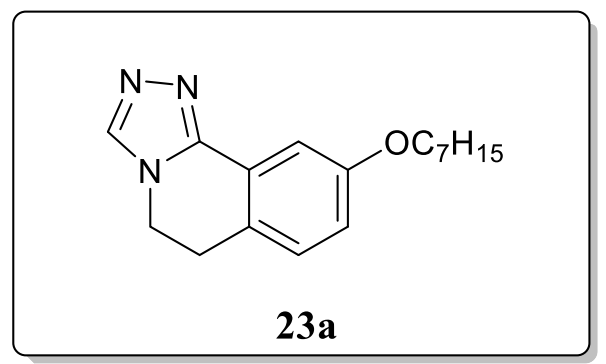

Mahdavi et al. synthesized a novel series of 3Amino-5-[4-chloro-2-phenoxyphenyl]-4H-1,2,4-triazoles derivatives and evaluated for their anti-epileptic activity. Result showed that the only compound 24a was found to have the most significant activity as compared with the reference drug [53].

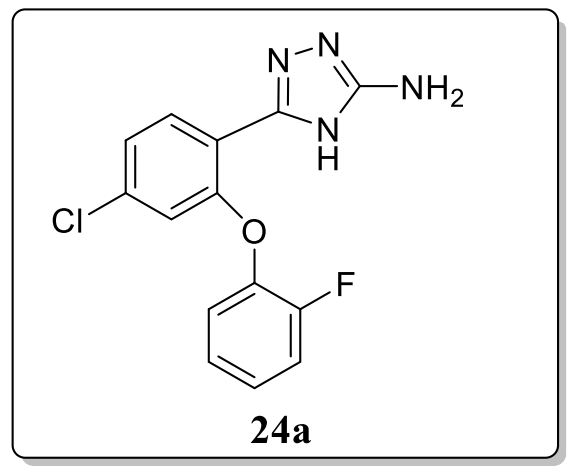

Song et al. reported a new series of 4-(2(alkylthio)benzo[d]oxazol-5-yl)-2,4-dihydro-3H-1,2,4triazol-3-one derivatives and evaluated their anticonvulsant activity. Two seizure models, the maximal electroshock seizure (MES) and subcutaneous pentylenetetrazole (scPTZ), were used for the anticonvulsant activity. From the result, only compound 25a was found to be most significant compound with $\mathrm{ED}_{50}$ values of 23.7 and $18.9 \mathrm{mg} / \mathrm{kg}$, respectively. Furthermore, the seizure-preventing action of compound 25a the anticonvulsant activity confirmed by the 3-MP- and BIC-induced seizure models [54].

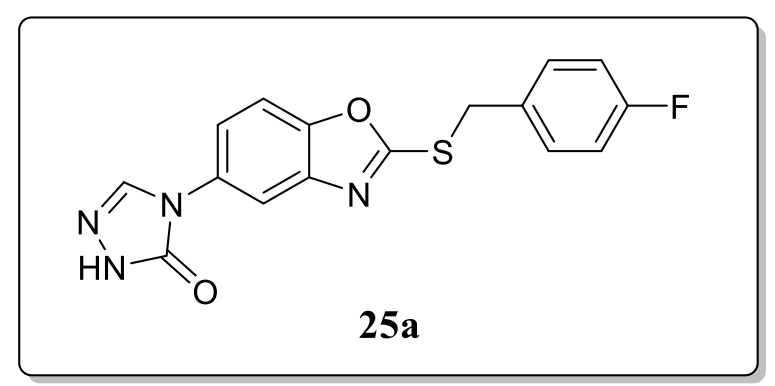

Dehestani et al. synthesized twelve phenacyl triazole hydrazone derivatives and screened their in vivo anticonvulsant activity by using the MES and PTZ seizure models. All synthesized derivatives are characterized by spectral analysis. Among the series, compound 26a revealed the significant activity in both models. The computational studies of compound 26a with different targets hypothesize that the compound acts mainly as a $\mathrm{GABA}_{\mathrm{A}}$ receptor [55].

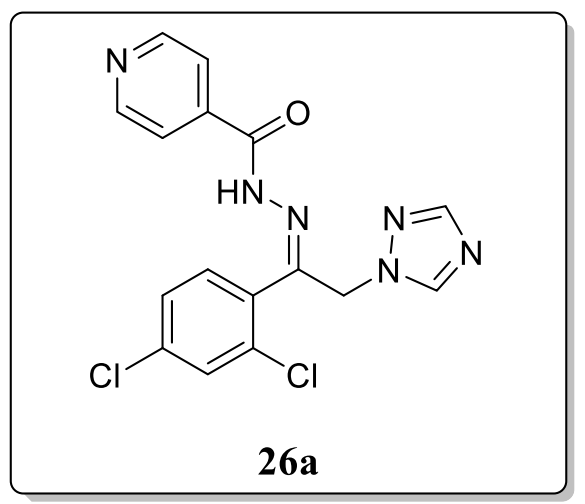

Deng et al. reported a novel series of 7-phenyl-6,7dihydro - $[1,2,4]$ triazolo[1,5-a]pyrimidine-5(4H)-ones derivatives and evaluated their anticonvulsant activity. Most of the synthesized derivatives showed the significant activity in the MES model. Out of all derivatives, compound 27a displayed the most potent anticonvulsant activity with $\mathrm{ED}_{50}$ value $19.7 \mathrm{mg} / \mathrm{kg}$ [56].

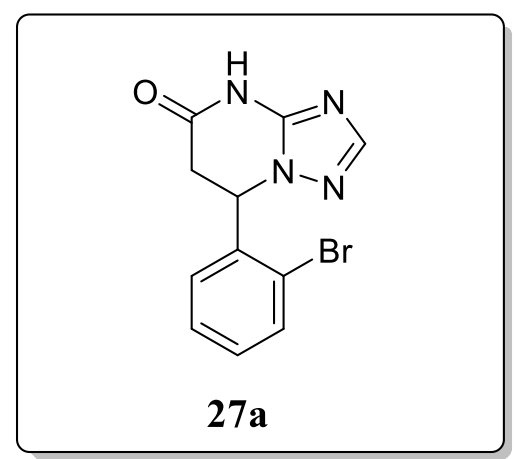


Siddiqui et al. synthesized various triazoles containing thiazole derivatives. The two most active compounds 47 and 48 were tested in the Phase II anticonvulsant study for their anticonvulsant activity $\left(\mathrm{ED}_{50}\right)$ and neurotoxicity $\left(\mathrm{TD}_{50}\right)$. And anticonvulsant action was carried out by two methods mostly using the electroshock (MES) and chemo shock (scPTZ) models. From the result, compounds 28a and 28b exhibited the potent anticonvulsant activity [57].
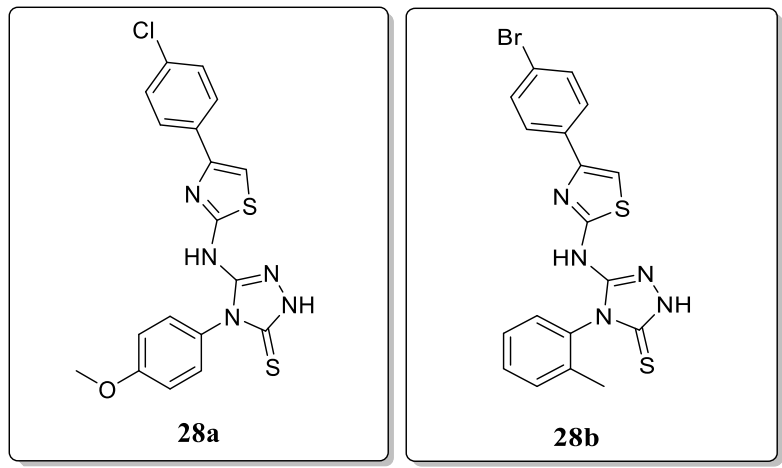

Zheng et al. synthesized a novel series of 4-(4-substitutedphenyl)-3-methyl-1H-1,2,4-triazole-5(4H)-one derivatives and evaluated their anticonvulsant activity. All the synthesized derivatives were characterized by NMR, IR, and mass spectroscopy. Among the series, compound 29a was found to have the most promising activity with $\mathrm{ED}_{50}$ value of $25.5 \mathrm{mg} / \mathrm{kg}$ [58].

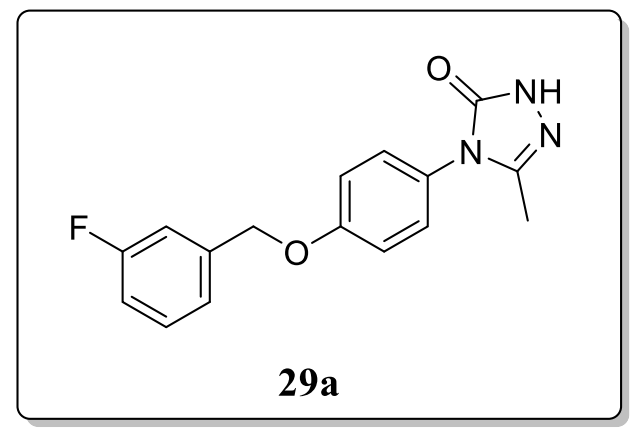

\section{Analgesic and anti-inflammatory activity}

Tariq et al. reported a novel class of N-[3-(substituted4H-1,2,4-triazol-4-yl)]benzo-(d)] thiazol-2-amine derivatives and evaluated for their in vivo anti-inflammatory activity. From the result, only compound 30a displayed the most potent in vivo anti-inflammatory [59].

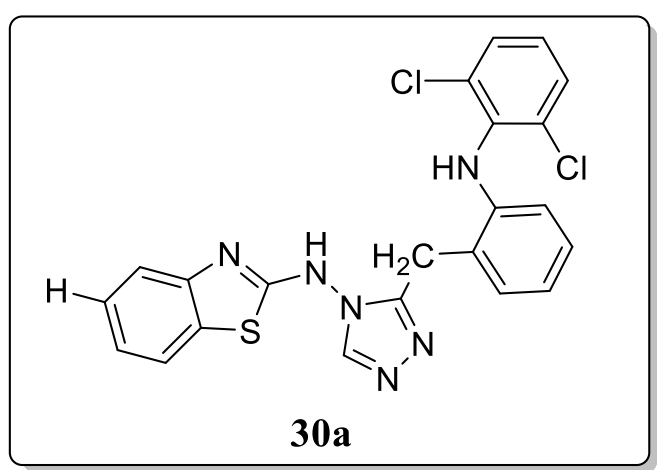

Ahirwar et al. reported a new series of substituted benzyl groups via thio-linkage and potential merged pharmacophore containing 1,2,4-triazoles and evaluated their analgesic and anti-inflammatory activities in mice and rats, respectively. Among all these derivatives, 3-(5-(2,4-dimethylbenzylthio)$4 \mathrm{H}-1,2,4-$ triazol-3-yl) pyridine $31 \mathrm{a}$ showed excellent antiinflammatory activity, and 3-(5-(4-nitrobenzylthio)-4H-1,2,4triazol-3-yl) pyridine 31b showed significant analgesic activity [60].
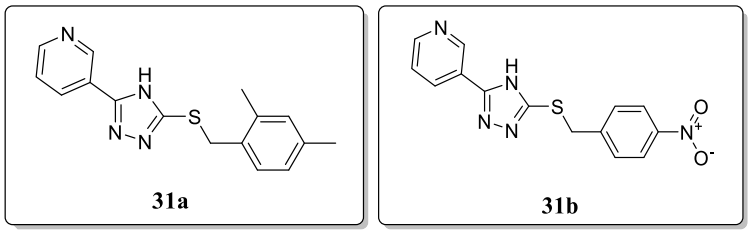

Khan et al. reported and investigated a new series of five membered heterocyclic derivative containing three hetero atoms for their in vivo anti-inflammatory activity. Among all the synthesized compounds, only compound 32a showed the potent anti-inflammatory activity with $56.49 \%$ inhibition and the rest of the compounds showed moderate activity. And analgesic activity of all derivatives ranges between 27.50 and $65.24 \%$ as compared with the controlled drug [61].

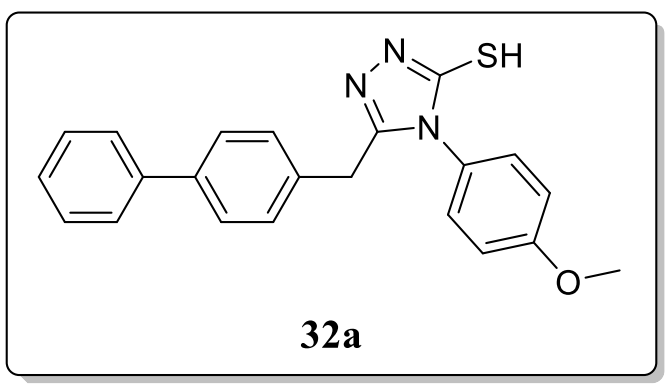


Zhang et al. synthesized a novel series of pyrimidine derivatives containing triazole and investigate their antiinflammatory activity. Result revealed that the compound 33a showed the significant anti-inflammatory activity with an inhibition rate of $49.26 \%$. And other western blotting showed the dose-dependent NF-SB (p65) activation and MAPK (ERK) and p38-phosphorylation in dose response and concentration dependent manner is inhibited by this compound extract [62].

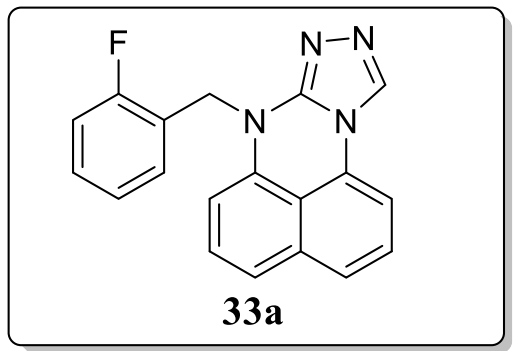

Sarigol et al. synthesized some thiazolo[3,2-b]-1,2,4triazole- $6(5 \mathrm{H})$-one derivatives and screened for their invivo analgesic and anti-inflammatory activity. Out of all derivatives, compound $\mathbf{3 4 a}$ had the most selective COX2 inhibition of all tested compounds and significant analgesic and anti-inflammatory activity [63].

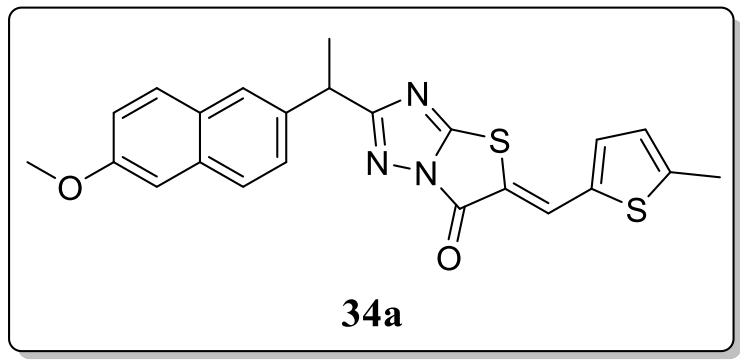

Almasirad et al. reported a new series of novel 1,2,4triazole derivatives and screened their analgesic activity. And analgesic activity was evaluated by formalininduced nociception test. Result revealed that the compound 35a with the inhibition rate $49.38 \%$ in early phase and $79.62 \%$ in late phase showed the potent analgesic activity [64].

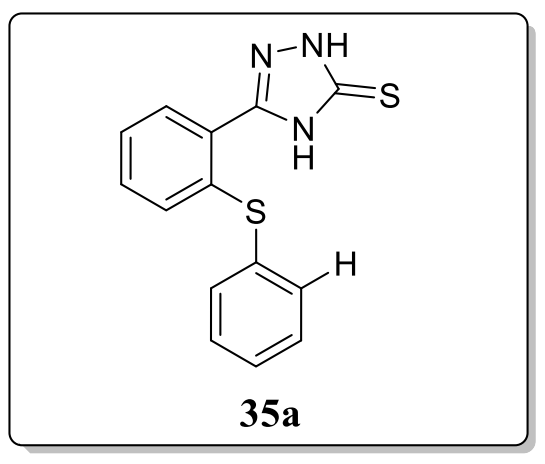

Haider et al. synthesized a series of 1,2,3-triazolebased benzoxazolinone and screened for their COX-2 inhibitory activity. From the result, compound 36a exhibited the potent selective COX-2 inhibition (COX-1 $\mathrm{IC}_{50}$ $=174.72 \mu \mathrm{M}$; COX-2 $\mathrm{IC}_{50}=2.4 \mu \mathrm{M}$ ) as compared with celecoxib. And the selective index of this compound shows the selective nature of the compound towards COX-2 inhibition. Compound 36b also exhibited the significant antinociceptive activity [65].
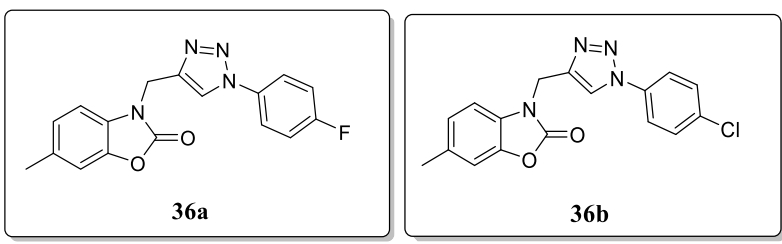

Syed Shaf et al. reported a novel series of bis-hetero cycles containing 2-mercapto benzothiazole-based 1,2,3triazole and screened their anti-inflammatory activity. From the result, compound 37 a display the significant selective COX-2 inhibition activity as compared with the standard drug and compound $3 \mathbf{3} \mathbf{b}$ also exhibited the comparable analgesic activity [66].
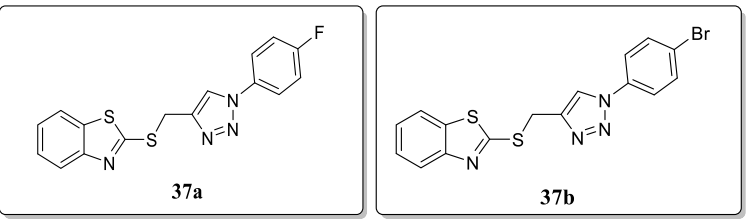
Gamal El-Din A.A. et al. described a novel series of 1-[4-(Aminosulfonyl)phenyl]-1H-1,2,4-triazole derivatives. All the synthesized derivatives were confirmed by different spectroscopic method. Among the tested series, compounds 38a, 38b, 38c, and 38d exhibited potent anti-inflammatory activity. SAR studies demonstrated that the substitution of 4-methoxyphenyl (38a), 4-methylphenyl (38b), 4-acetylphenyl (38c), and 3,4-dimethoxyphenyl (38d) groups also increase antiinflammatory activity as compared with the other derivatives [67].
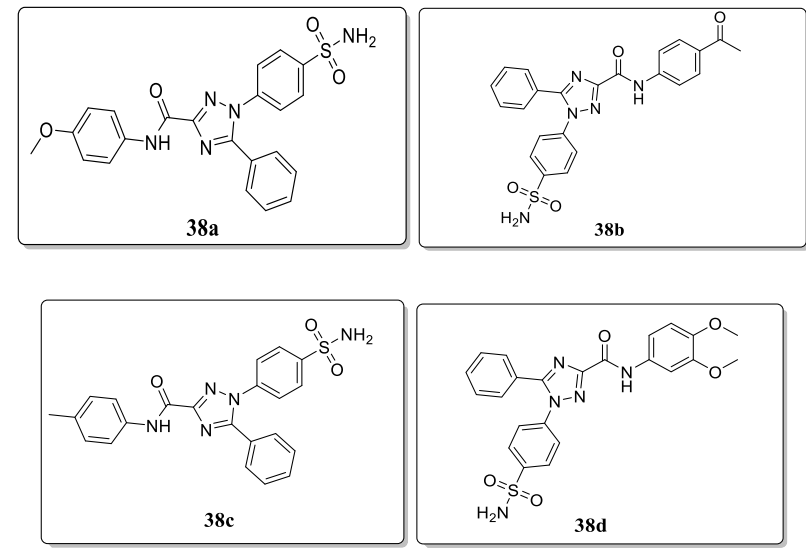

Tozkoparan et al. synthesized a novel series of 5-aryl-3alkylthio-1,2,4-triazole derivatives and screened their antiinflammatory activity. All the synthesized derivatives were characterized by spectral and elemental analysis. Among the series, compounds 39a and 39b exhibited potent analgesic and antiinflammatory activities with no ulcerogenic effect [68].
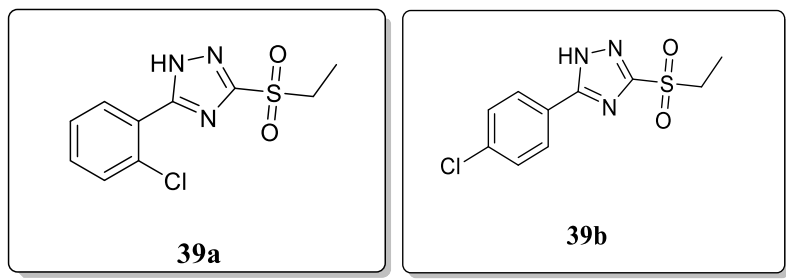

Kaur et al. described a novel series of 1,4-diaryl-substituted triazoles was synthesized and evaluated for their COX-2 inhibition. From the result, only compound 40a displayed excellent COX-2 activity [69].

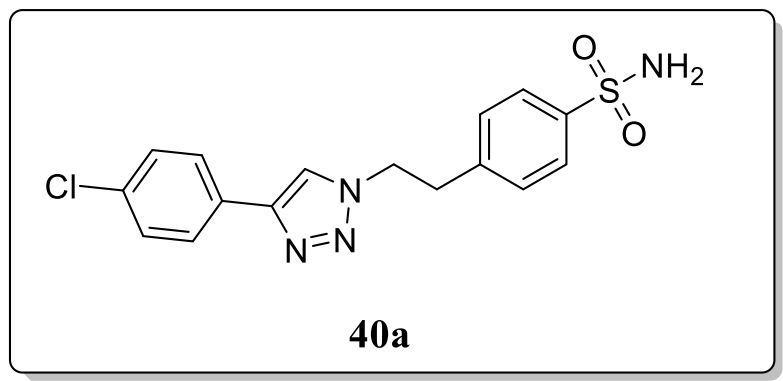

\section{Anticancer activity}

Mahanti et al. reported a series of fused acridine containing 1,2,4-triazole derivatives. And screened their anti-proliferative activity towards several human cell lines including, MCF7 (Breast), A549 (Lung), A375 (Melanoma), and HT-29 (Colon). The $\mathrm{IC}_{50}$ value of target compound in range between $0.11 \pm 0.02$ and $13.8 \pm 0.99 \mu \mathrm{M}$ as compared with the standard range $0.11 \pm 0.02$ to 0.93 $\pm 0.056 \mu \mathrm{M}$. Result revealed that the compounds 41a-41c exhibited the excellent anticancer activity. SAR investigations of this series revealed that introduction of 4-chloro, 3,4,5- $\left(\mathrm{CH}_{3} \mathrm{O}\right)_{3}$, and 4$\mathrm{CF}_{3} \mathrm{CH}_{3}$ groups at para-position of the phenylring displayed the significant anticancer activity [70].

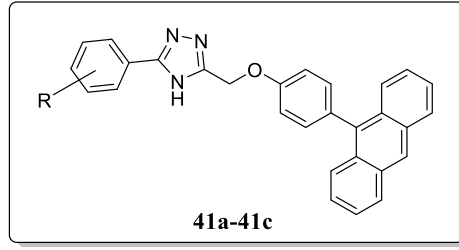

\begin{tabular}{|c|c|}
\hline Comp. & $\mathbf{R}$ \\
\hline $\mathbf{4 1 a}$ & 3,4,5-trimethoxy \\
\hline $\mathbf{4 1 \mathbf { b }}$ & 4-chloro \\
\hline $\mathbf{4 1 c}$ & 4-trifluromethyl \\
\hline
\end{tabular}

Al-Wahaibi et al. reported a novel series of 1,2, 4-Triazolyl coumarin derivatives and evaluated their anti-proliferative activity towards human colon cancer cell line (HCT116). Result showed that the compound 42a exhibited antiproliferative activity with $\mathrm{IC}_{50}$ values $4.363 \mu \mathrm{M}$ respectively [71].

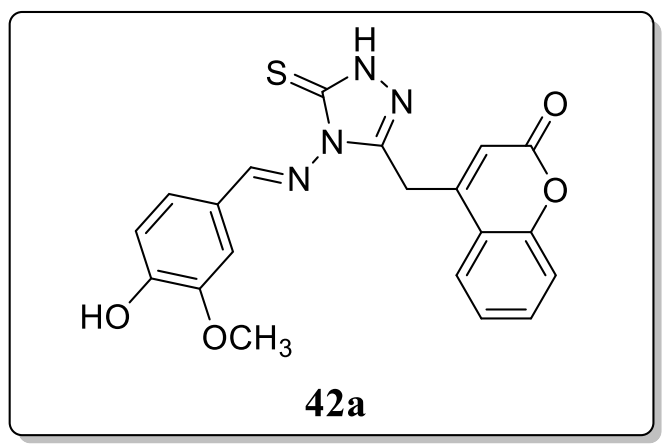

Ma et al. synthesized a new series of 1,2,3-triazolepyrimidine-urea derivatives and evaluated their antiproliferative activity against selected four different human tumour cell lines including MCF-7, MGC-803, EC-109, and B16-F10. The compounds 43a-43c exhibited significant growth inhibition against B16-F10 with $\mathrm{IC}_{50}$ values of $32 \mu \mathrm{M}, 35 \mu \mathrm{M}$, and $42 \mu \mathrm{M}$ among all the tested compounds [72]. 


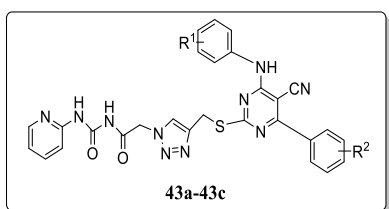

\begin{tabular}{|c|c|c|}
\hline Comp. & $\mathbf{R}^{\mathbf{1}}$ & $\mathbf{R}^{\mathbf{2}}$ \\
\hline 43a & $\mathrm{P}-\mathrm{CH} 3$ & $3,4,5$-Trimethoxylpheny1 \\
\hline $\mathbf{4 3 b}$ & $\mathrm{p}-\mathrm{CH}(\mathrm{CH} 3)$ & $\mathrm{p}-\mathrm{CH} 3$ \\
\hline $\mathbf{4 3 c}$ & $\mathrm{p}-\mathrm{CH}(\mathrm{CH} 3) 2$ & $\mathrm{p}-\mathrm{Br}$ \\
\hline
\end{tabular}

Ma et al. reported a novel series of 1,2,3-triazole-pyramidine hybrid derivatives and screened their cytotoxic potential towards several tumour cell lines. Among these synthesized compounds, the compound 44a exhibited the potent and selective anti-proliferative activity with $\mathrm{IC}_{50}$ values in range between 1.42 and $6.52 \mu \mathrm{M}$. Particularly, studies revealed that the compound 44a also inhibit the growth of EC-109 cancer cells via apoptosis-inducing activity and cell cycle arrest at G2/M phase [73].

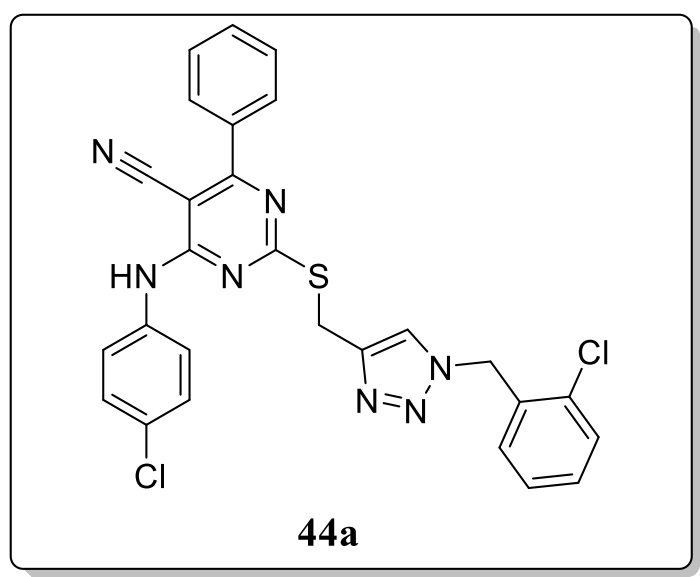

Duan et al. synthesized a new series of 1,2,3-triazole-dithiocarbamate hybrids and screened their anticancer activity against four different selected human cancer cell lines including MCF-7, PC-3, MGC-803, and EC-109. Among these, the compounds $45 a$ and $45 b$ showed significant wide-spectrum activity. Compound $45 \mathbf{a}$ was found to be most potent towards selected four different human cancer cell lines as compared with 5-fluorouracil [74].
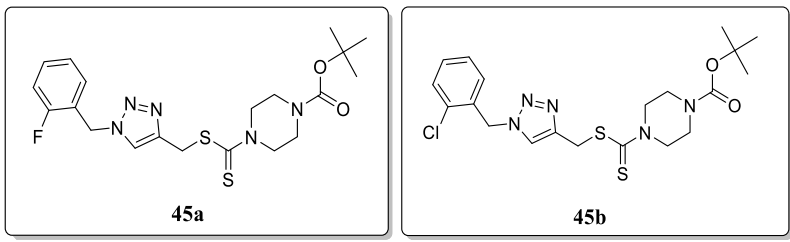

Aouad et al. reported a novel series of benzothiazolepiperazine-1,2,3-triazole hybrids and investigated their anti-proliferative activity against different human cancer cell lines. Some hybrid molecules showed significant antiproliferative activity. ADME and $\operatorname{clog} \mathrm{P}$ analysis method confirmed the biological profile. From the result, compound 46a exhibited the remarkable antiproliferative activity [75].

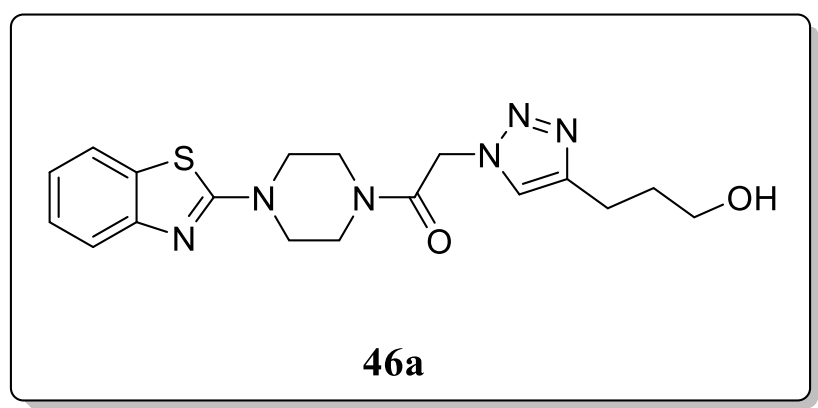

Ashwin et al. reported a novel series of 1,2,3-triazole derivatives and screened their anticancer activity against acute myeloid leukemia cell lines. Result revealed that, compound 47a exhibited the significant anticancer activity with an $\mathrm{IC}_{50}$ of $2 \mu \mathrm{M}$ towards MV4-11 cells [76].

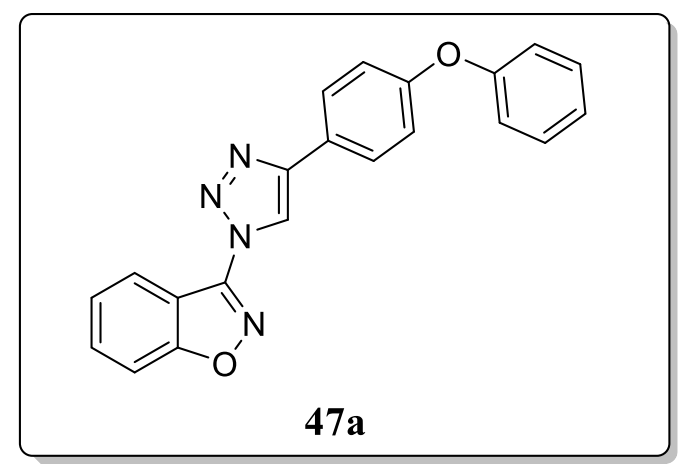

Dhawan et al. reported a new series of coumarintagged $\beta$-lactam triazole hybrids and evaluated for their anticancer activity against different cancer cell lines (MDA-MB-231, MCF7, A549) and one control cell line HEK293. Among the tested series, compounds 48a and 48b exhibited excellent activity against MCF-7 cancer cell line with $\mathrm{IC}_{50}$ values of 53.55 and $58.62 \mu \mathrm{M}$ and no cytotoxicity against normal cell line. SAR studies revealed that the presence of nitro and chloro groups at $\mathrm{C}-3$ position of the phenyl ring also enhance their activity against MCF-7 cell line [77].
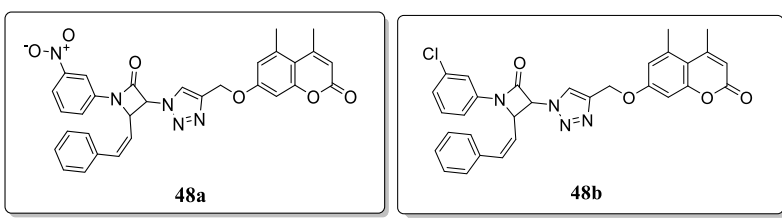

Saftic et al. synthesized 8-triazolyl acyclovir derivatives for in vitro evaluation of cytostatic activity against Madine Darby canine kidney (MDCK I) cells and 
different tumour cell lines. From the result, compound 49a with the shortest alkyl substituent at the triazole ring showed significant inhibitory activity against the CaCo-2 cell line but low cytotoxic effect on normal MDCK I cells [78].

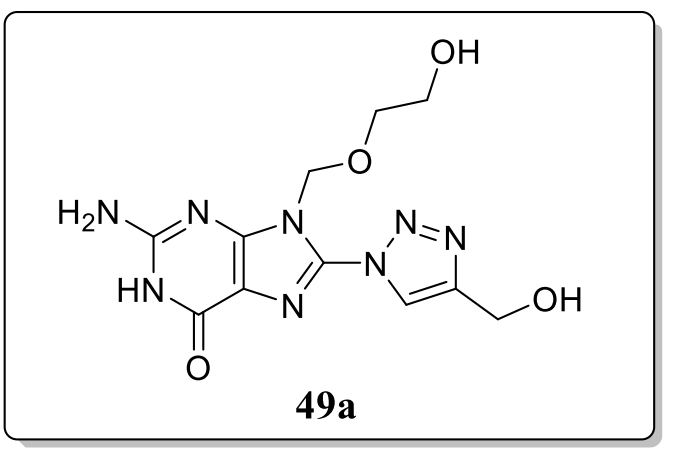

\section{Antidiabetic activity}

Saeedi et al. reported the quinazolinone-1,2,3-triazole hybrid derivatives and screened their in vitro $\alpha$ glucosidase inhibitory activity as leading to an effective antidiabetic agent. All these derivatives displayed excellent antidiabetic activity with $\mathrm{IC}_{50}$ values ranging between 181.0 and $474.5 \mu \mathrm{M}$ and were found to be more potent than reference drug acarbose $\left(\mathrm{IC}_{50}=750.0\right)$. Result showed that the compounds 50a and 50b where 4bromobenzyl moiety substituted to the 1,2,3-triazole ring exhibited excellent inhibitory activity with $\left(\mathrm{IC}_{50}=181.0\right.$ $\pm 1.4)$ and $\left(\mathrm{IC}_{50}=192.3 \pm 1.8\right)$. Furthermore, in silico docking studies showed the binding mode of these analogues on the active site of $\alpha$-glucosidase [79].

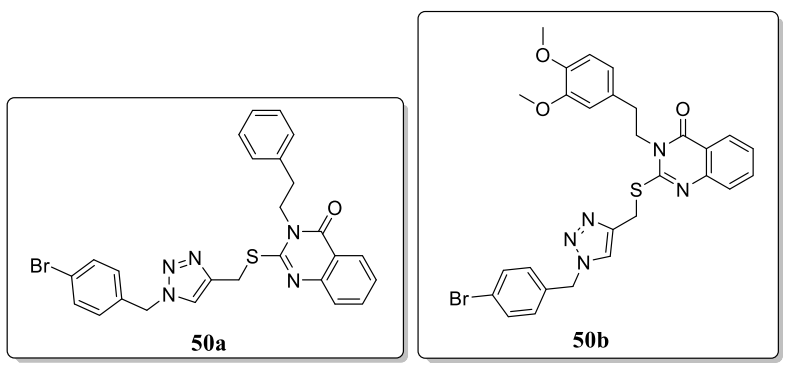

Avula et al. synthesized a class of novel 1,2,3-triazole analogues were synthesized and evaluated their $\alpha$ glucosidase inhibitory activity in ranges between 14.2 and $218.1 \mu \mathrm{M}$. Result revealed that the compound 51a exhibited the most effective antidiabetic activity as compared with the reference drug. And the activity of this compound is 67 times better than the reference due to the presence of the methoxy phenyl group [80].

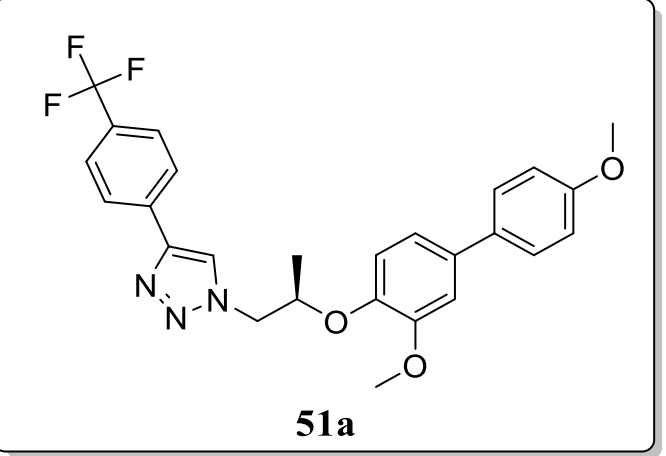

Wang et al. synthesized a novel series of triazinetriazole derivatives and evaluated their antidiabetic activity. All these derivatives exhibited the potent antidiabetic activity. Out of all synthesized compounds, compound 52a showed potent $\alpha$-glucosidase inhibitory activity [14].

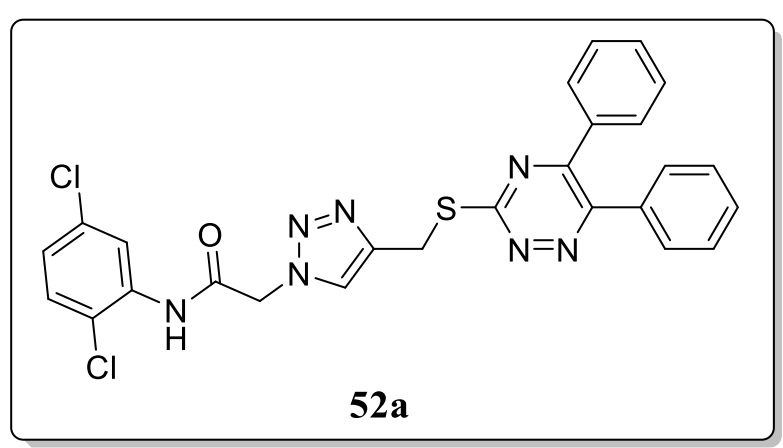

Chinthala et al. reported a novel series of chalcone-1, 2,3 -triazole hybrids and screened their $\alpha$-glucosidase inhibitor activity. These hybrids exhibited the potential antidiabetic activity. Result showed that the compounds 53a, 53b, and 53c with $\mathrm{IC}_{50}$ values of $67.77 \mu \mathrm{M}, 74.94$ $\mu \mathrm{M}$, and $102.10 \mu \mathrm{M}$, respectively, exhibited potent $\alpha$ glucosidase inhibition. Furthermore, the docking studies showed these compounds target the $\alpha$-glucosidase in range 100.37 to 107.78 [81].

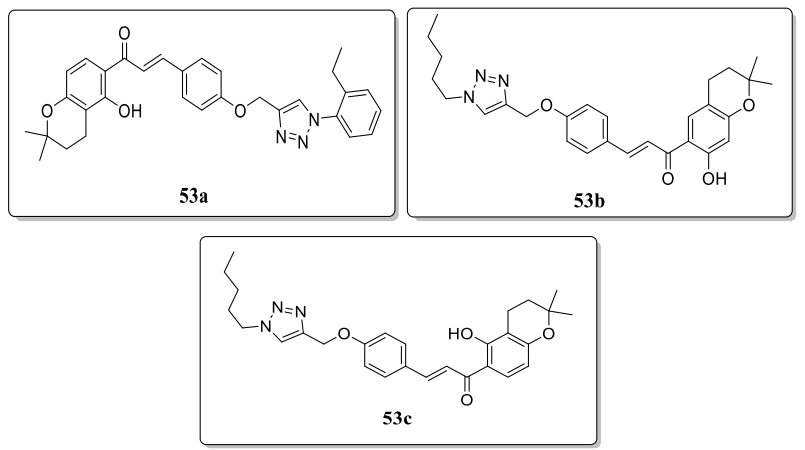


Gonzaga et al. synthesized 1-phenyl-1H-2-phenyl-2H1,2,3-triazol derivatives and screened their $\alpha$-glucosidase and porcine pancreatic $\alpha$-amylase activity. All compounds tested at $500 \mu \mathrm{M}$, only compound $\mathbf{5 4 a}$ was found to have the most significant antidiabetic activity with $54 \mu \mathrm{M}$ as compared with acarbose [82].

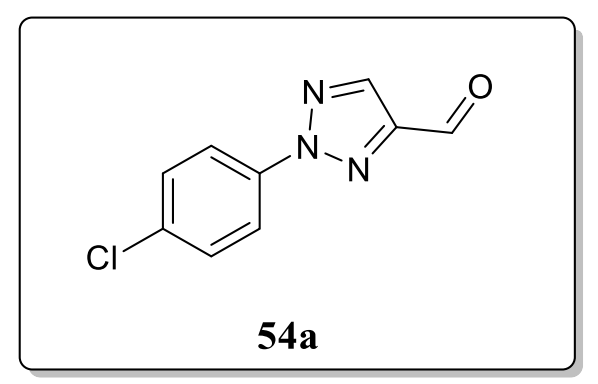

\section{Antiviral activity}

Ju et al. reported a new class of 1,2,3-triazole oseltamivir analogues and screened their antiviral activity against three different strains (H5N1, H5N2, H5N6) in both enzymatic assay and cellular assay. From the result, compound 55a exhibited the broad-spectrum antiviral activity with $\mathrm{IC}_{50}$ value $0.12 \mu \mathrm{M}, 0.049 \mu \mathrm{M}$, and $0.16 \mu \mathrm{M}$ against three different strains [83].

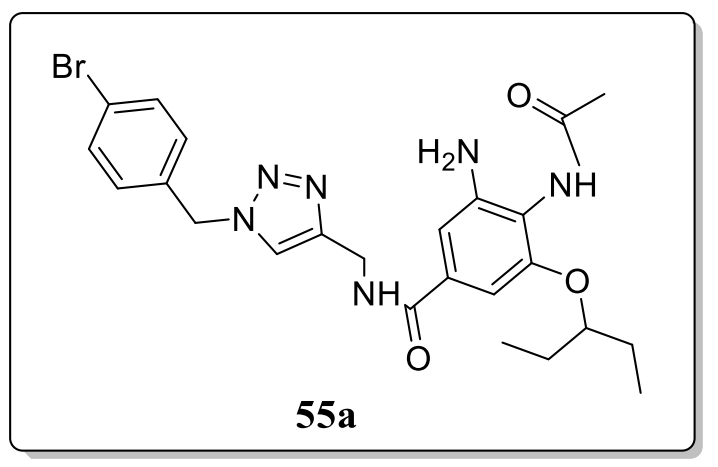

Jordao et al. synthesized a novel series of $\mathrm{N}$-amino1,2,3-triazole compounds and screened their antiviral activity against Cantagalo virus. All derivatives were characterized by IR, ${ }^{1} \mathrm{H}$, and ${ }^{13} \mathrm{C}$ spectroscopy and elemental analysis. From the result, compound 56a revealed the excellent antiviral activity [84].<smiles>Cc1c(C(=O)NN)nnn1Nc1ccc(F)cc1</smiles>

$56 \mathbf{a}$
Kucukguzel et al. investigated a new series of novel thiourea containing triazole derivatives and tested their anti-HIV activity. Structures of synthesized derivatives were confirmed by elemental and spectral analysis. Result revealed that the compound 57a exhibited the significant anti-HIV activity towards Coxsackie virus B4. SAR studies revealed that, the presence of the allyl group at N-4 of the 1,2,4-triazole ring and phenyl ring at terminal nitrogen of thioureas enhanced their activity [85].

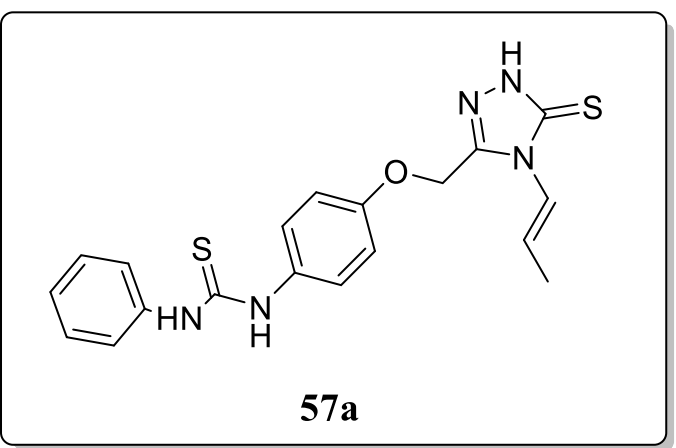

Wang et al. reported a novel series of sulfanyl-triazole derivatives as an HIV-1 non-nucleoside reverse transcriptase inhibitor by using high throughput screening. It exhibited significant activities against the selected resistant mutants. From the result, compound 58a exhibited excellent anti-HIV activity [86].

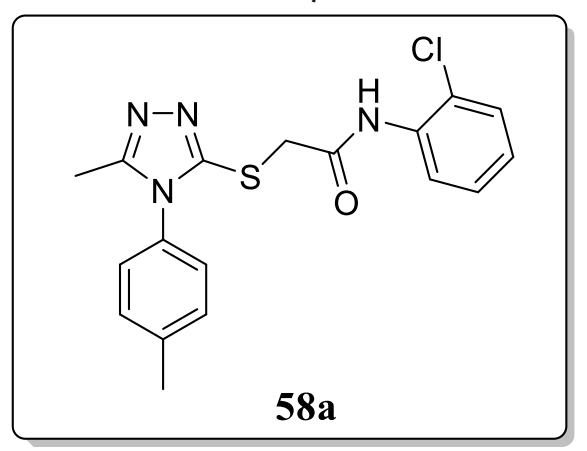

Karypidou et al. synthesized a series of fused 1,2,3triazole derivatives as potential antiviral agent. All the derivatives were screened against some variety of viruses (HIV-1, HIV-2, vaccinia virus, adenovirus-2, and coronavirus) in HEL cells and their inhibitory activity was compared with standard drugs. Among all the tested series, compound 59a $\left(\mathrm{EC}_{50}=8.95\right.$ $\mu \mathrm{M})$ and 59b $\left(\mathrm{EC}_{50}=8.90 \mu \mathrm{M}\right)$ exhibited the moderate activity against human coronavirus [87]. 

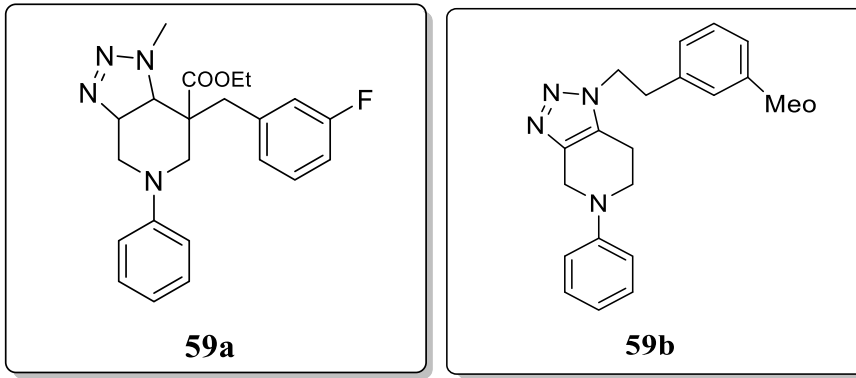

Cao et al. synthesized novel triazole derivatives for in vitro antiviral activity against EV71 and CVB3 in cellbased assay. All the synthesized derivatives were characterized by various spectroscopic methods including ${ }^{1} \mathrm{H}$ NMR, ${ }^{13} \mathrm{C}$ NMR, and mass spectroscopy. Among the result, only compound 60a exhibited remarkable antiviral activities against EV71 and CVB3 virus with the $\mathrm{EC}_{50}$ value of $5.3 \pm 0.7$ and $10.1 \pm 3.8 \mu \mathrm{g} / \mathrm{mL}$ as compared with the control ribavirin [88].

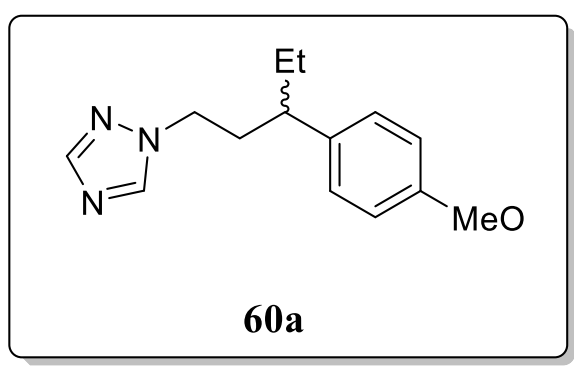

Mohammed et al. reported 1,2,3-triazoles as amide bio-isosteres and evaluated for their antiviral activity against H9 and MT4 cells. Result revealed that the 1,4disubstituted-1,2,3-triazole based derivatives 61a was found to have significant anti-HIV activity against only $\mathrm{H} 9$ cells $\left(\mathrm{IC}_{50}=1.2 \mu \mathrm{M}\right.$ in $\mathrm{H} 9$ cells $)$ and no activity against MT4 cells [89].

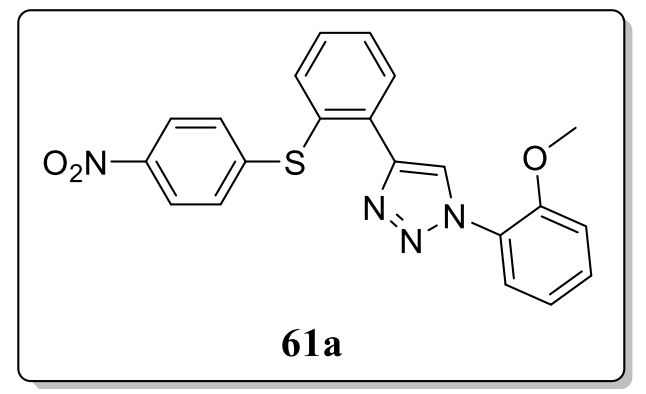

\section{Antimalarial activity}

Oramas-Royo et al. reported and investigated a new series of 1,2,3-triazole-napthaquinone derivatives. Several of these compounds were tested for their in vitro antimalarial activity towards Plasmodium falciparum strains. From the result, compounds $62 \mathbf{a}$ and $\mathbf{6 2 b}$ exhibited potent antimalarial activity with $\mathrm{IC}_{50}$ values of 0.8 and $1.2 \mu \mathrm{M}$. SAR studies revealed that the compound 62a bearing a fluoro group at C-3 and a methoxy group at $\mathrm{C}-4$ and compound $\mathbf{6 2 b}$ with an unsubstituted phenyl ring enhanced the antimalarial activity [90].
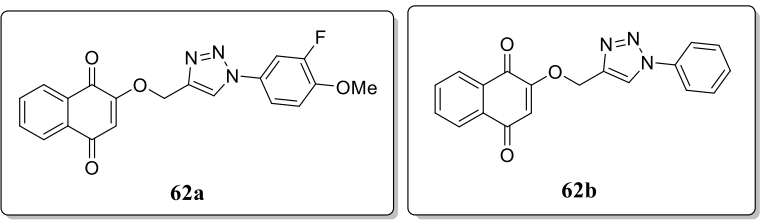

Thakur et al. synthesized a novel series of glycosylated 1,2,3-triazolyl-methyl-indoline-2,3-dione derivatives via acid catalyzed reaction and evaluated their anti-plasmodial activity. Among them, compounds 63a and 63b exhibited the good activity against resistant strain pfk1 with $\mathrm{IC}_{50}$ values 1.61 and 1.93 $\mu \mathrm{M}$, respectively [91].
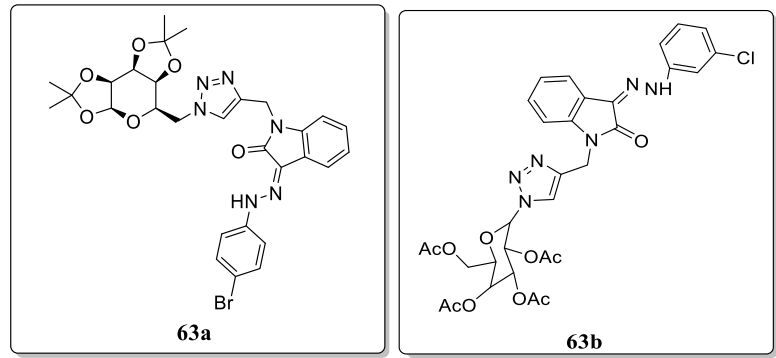

Thakkar et al. reported new ten compounds containing 1,2,4-triazole and evaluated their in vitro antimalarial activity against $P$. falciparum strain. All these synthesized derivatives were characterized by IR, ${ }^{1} \mathrm{H}$ NMR, ${ }^{13} \mathrm{C}$ NMR, mass spectroscopy, and elemental analysis. From the result, compounds 64a, 64b, and 64c exhibited the potent antimalarial activity with $\mathrm{IC}_{50}$ values $0.282,0.245$, and $0.230 \mu \mathrm{M}$ as compared with the reference drug chloroquine Pyrimethamine. SAR studies revealed that introduction of $4-\mathrm{OH}, 3-\mathrm{NO}_{2}, 4-\mathrm{CL}$ in the phenyl group enhance activity [92].

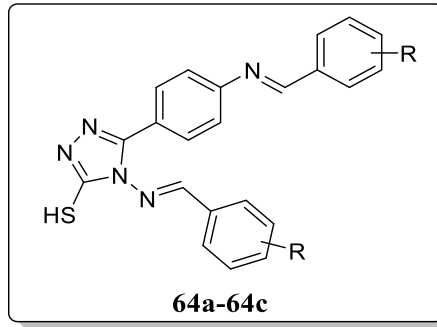

\begin{tabular}{|c|c|}
\hline Comp. & $\mathbf{R}$ \\
\hline $\mathbf{6 4 a}$ & $4-\mathrm{OH}$ \\
\hline $\mathbf{6 4 b}$ & $3-\mathrm{NO}_{2}$ \\
\hline $\mathbf{6 4 c}$ & $4-\mathrm{CL}$ \\
\hline
\end{tabular}


Table 3 Some triazole nucleus-containing drugs in market and their clinical use [94-105]

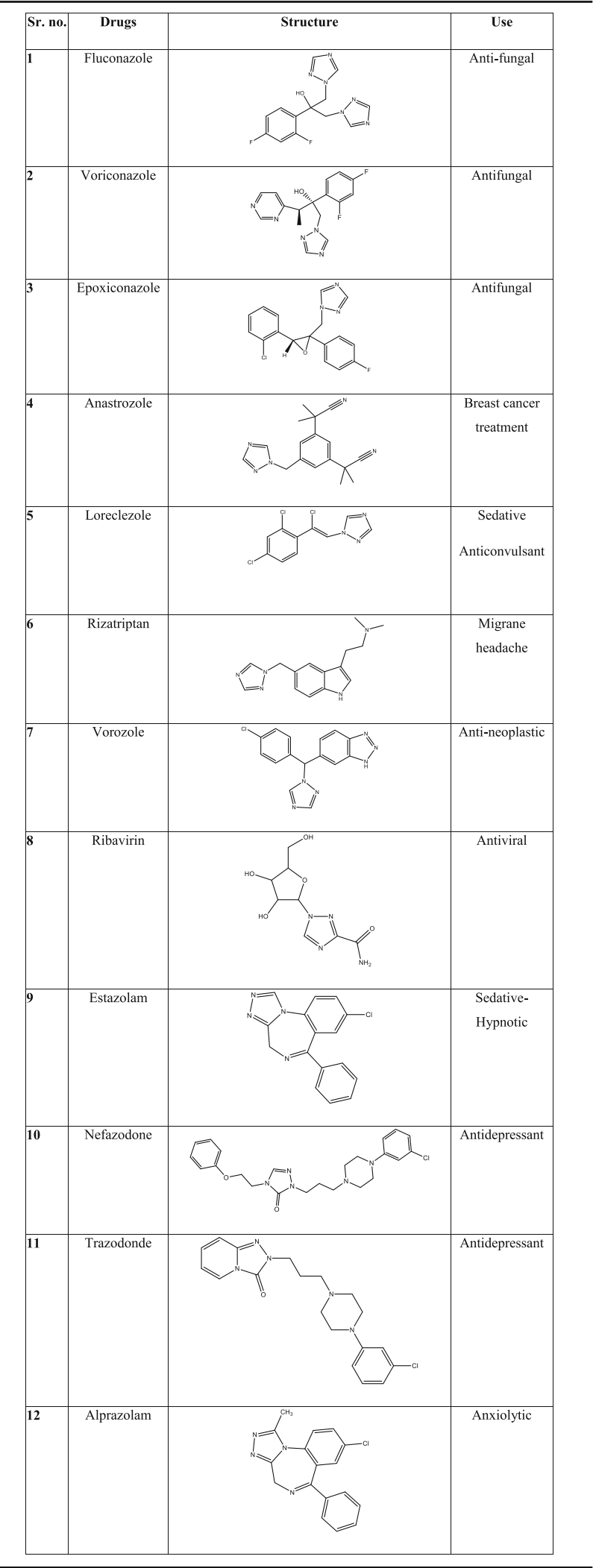

Joshi et al. synthesized a novel series of quinoline triazole amide analogues and screened for their antimalarial activity against different strains (CQS D10 and CQR K1). It was concluded that the compounds $65 \mathbf{a}, 65 \mathbf{b}$, and 65c showed most potent activity towards $P$. falciparum CQS D10 strain with $\mathrm{IC}_{50}$ values in the range between 349 and $1247 \mu \mathrm{M}$, and these compounds also exhibited similar activity against CQR K1 strain of parasite [93].

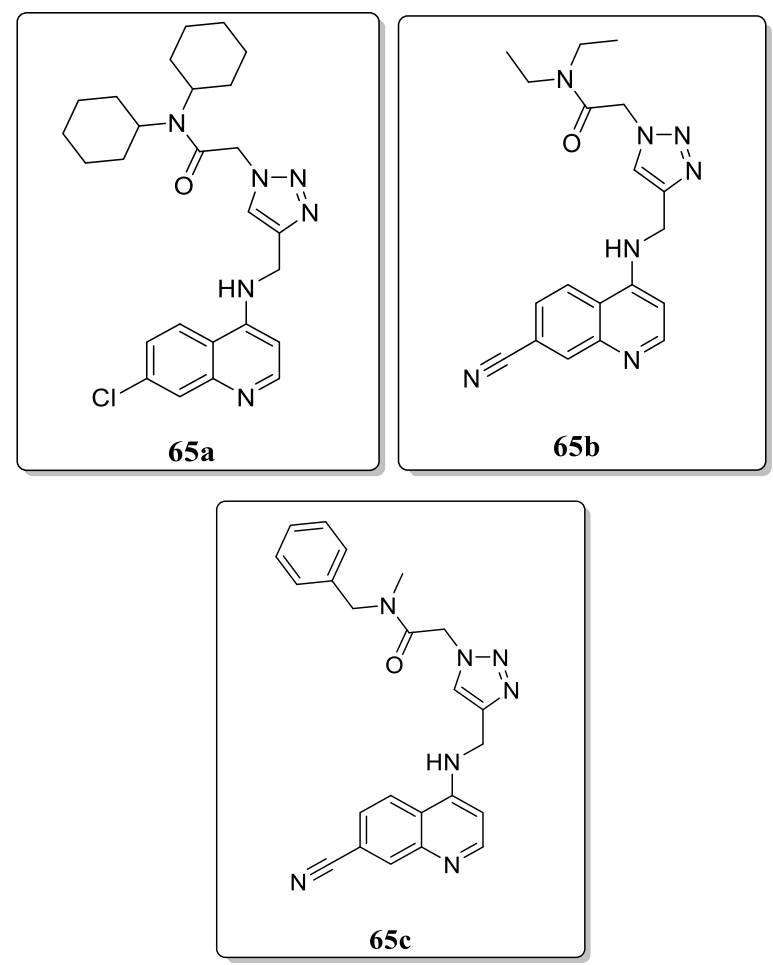

Guantai et al. synthesized a new triazole-linked chalcone and dienone hybrids and evaluated in vitro antimalarial activity. From the result, compound 66a was found to have the most significant activity against D10, DD2, and W2 strains of P. falciparum as compared with the reference drug chloroquine [94].

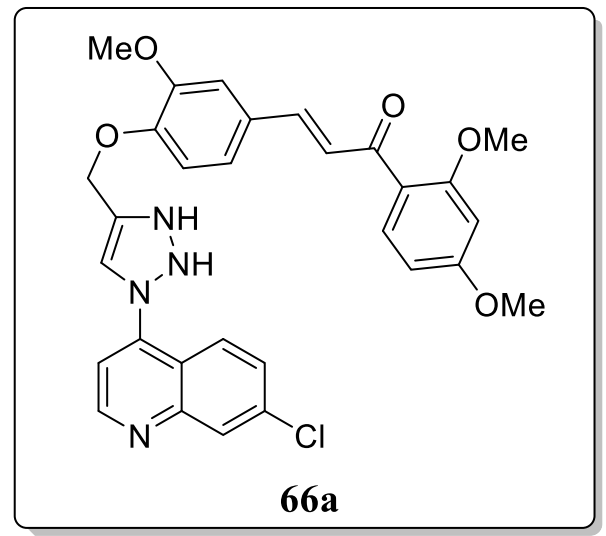


Tarawneh et al. synthesized a novel series of isoxazole and triazole derivatives and evaluated for their anti-infective agent. All the compounds were screened against $P$. falciparum D6 and W2 strains. From the result, the only compound $67 \mathrm{a}$ exhibited the most potent activity with $\mathrm{IC}_{50}$ values of 0.70 and $0.59 \mu \mathrm{M}$ against D6 and W2 strains [95].

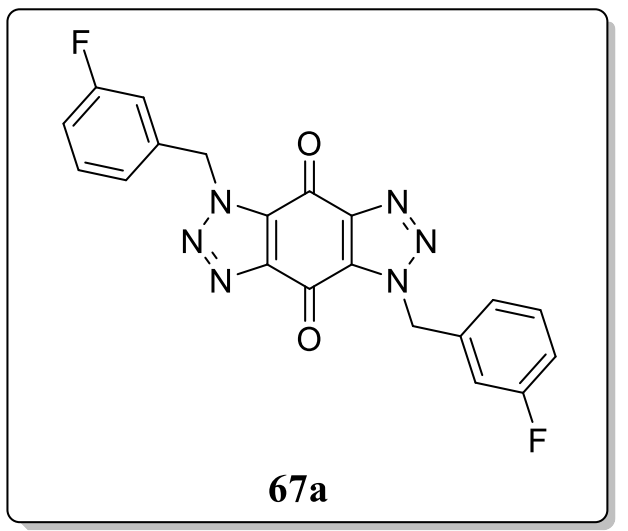

\section{Miscellaneous activities}

In spite of all these activities, triazoles are also active as antihypertensive agent 68a, neuroprotective agents $68 \mathrm{~b}$ and 68c, and diuretic 68d (Table 3). Triazole nucleus was found to possess significant atypical behaviour and good potency to block 5-HT receptors and good ability of selective antagonists towards the human vasopressin $\mathrm{V}_{1 \mathrm{~A}}$ receptor [96-99].

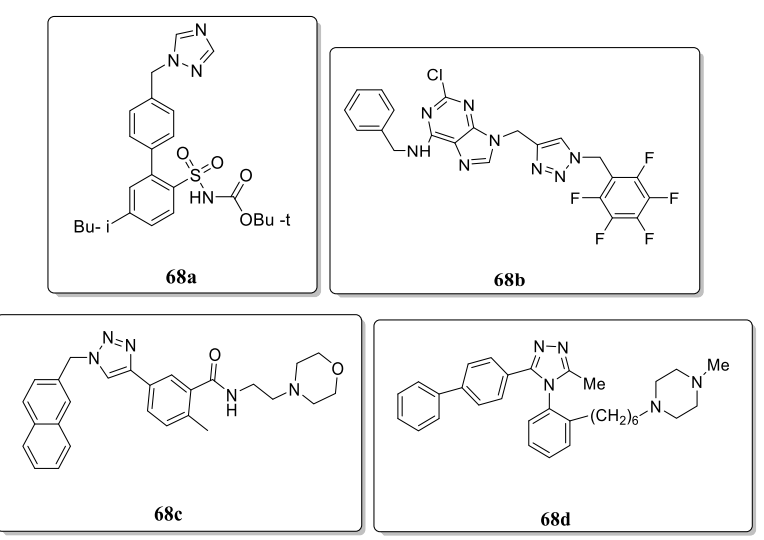

\section{Conclusion}

This review article highlights research work of many researchers reported in literature for different pharmacological activities on triazole compounds. Triazole has unique moiety that is responsible for various biological activities. The importance of triazole moiety can be magnified by carrying out further studies on its possible substitution and thus to synthesize better agents that can have strong future commitments. This review has presented comprehensive details of triazole analogues, potent compounds reported for particular pharmacological activity and the method or technique involved in evaluation process. More investigations must be carried out to evaluate more activities of triazole for many diseases whose treatment are difficult in the medical sciences.

\section{Abbreviations}

$\mathrm{IC}_{50}$ : Half maximal inhibitory concentration; SAR: Structure-activity relationship; $\mathrm{EC}_{50}$ : Median effective concentration required to induce a 50\% effect; COX: Cyclooxygenase; MBC: Minimum bactericidal concentration; MIC: Minimum inhibitory concentration; PEG: Polyethylene glycol; PI: Plaque index; IR: Infrared; NMR: Nuclear magnetic resonance

\section{Acknowledgement}

Not applicable

\section{Authors' contributions}

We declare that this work was done by the authors named in this article: SLK conceived and designed the study. SK carried out the literature collection of the data and writing of the manuscript. AY and SK assisted in the data analysis and corrected the manuscript. The authors read and approved the final manuscript.

\section{Funding}

Not applicable

\section{Availability of data and materials}

All the information in the manuscript has been referred from the included references and is available upon request from the corresponding author.

\section{Declarations}

Ethics approval and consent to participate

Not applicable

\section{Consent for publication}

Not applicable

\section{Competing interests}

The authors declare that they have no competing interests.

Received: 5 January 2021 Accepted: 3 April 2021

Published online: 25 May 2021

\section{References}

1. Pagniez F, Lebouvier N, Na YM, Ourliac-Garnier I, Picot C, Le Borgne M (2020) Biological exploration of a novel 1,2,4-triazole-indole hybrid molecule as antifungal agent. J Enzyme Inhib Med Chem 35(1):398-403. https://doi. org/10.1080/14756366.2019.1705292

2. Bozorov K, Zhao J, Aisa HA (2019) 1,2,3-Triazole-containing hybrids as leads in medicinal chemistry: a recent overview. Bioorg Med Chem 27(16):35113531. https://doi.org/10.1016/j.bmc.2019.07.005

3. Palko M, El Haimer M, Kormanyos Z, Fulop F (2019) Synthesis of novel Nheterocyclic compounds containing 1,2,3-triazole ring system via domino, "Click" and RDA reactions. Molecules 24(4):772-783. https://doi.org/10.3390/ molecules 24040772

4. Potts K (1961) The chemistry of 1, 2, 4-triazoles. J Chemical reviews 61(2):87127. https://doi.org/10.1021/cr60210a001

5. Ulloora S, Shabaraya R, Adhikari AV (2013) Facile synthesis of new imidazo[1,2-a]pyridines carrying 1,2,3-triazoles via click chemistry and their antiepileptic studies. Bioorg Med Chem Lett 23(11):3368-3372. https://doi. org/10.1016/j.bmcl.2013.03.086

6. Kadaba PK (1988) Triazolines. 14. 1,2,3-Triazolines and triazoles, a new class of anticonvulsants. Drug design and structure-activity relationships. J Med Chem 31 (1):196-203. https://doi.org/10.1021/jm00396a032 
7. Guan LP, Jin QH, Tian GR, Chai KY, Quan ZS (2007) Synthesis of some quinoline-2(1H)-one and 1, 2, 4-triazolo [4, 3-a] quinoline derivatives as potent anticonvulsants. J Pharm Pharm Sci 10:254-262

8. Padmavathi V, Sudhakar Reddy G, Padmaja A, Kondaiah P, Ali S (2009) Synthesis, antimicrobial and cytotoxic activities of 1,3,4-oxadiazoles, 1,3,4thiadiazoles and 1,2,4-triazoles. Eur J Med Chem 44(5):2106-2112. https:// doi.org/10.1016/j.ejmech.2008.10.012

9. Zoumpoulakis P, Camoutsis C, Pairas G, Sokovic M, Glamoclija J, Potamitis C, Pitsas A (2012) Synthesis of novel sulfonamide-1,2,4-triazoles, 1,3,4thiadiazoles and 1,3,4-oxadiazoles, as potential antibacterial and antifungal agents. Biological evaluation and conformational analysis studies. Bioorg Med Chem 20(4):1569-1583. https://doi.org/10.1016/j.bmc.2011.12.031

10. De La Rosa M, Kim HW, Gunic E, Jenket C, Boyle U, Koh YH, Korboukh I, Allan M, Zhang W, Chen H, Xu W (2006) Tri-substituted triazoles as potent non-nucleoside inhibitors of the HIV-1 reverse transcriptase. Bioorg Med Chem Lett 16(17):4444-4449. https://doi.org/10.1016/j.bmcl.2006.06.048

11. Dong WL, Liu ZX, Liu XH, Li ZM, Zhao WG (2010) Synthesis and antiviral activity of new acrylamide derivatives containing 1,2,3-thiadiazole as inhibitors of hepatitis B virus replication. Eur J Med Chem 45(5):1919-1926. https://doi.org/10.1016/j.ejmech.2010.01.032

12. Boechat $N$, Ferreira VF, Ferreira SB, de Lourdes GFM, de CdSF BMM, Costa MD, Lourenço MC, Pinto AC, Krettli AU, Aguiar AC (2011) Novel 1,2,3-triazole derivatives for use against Mycobacterium tuberculosis H37Rv (ATCC 27294) strain. J Med Chem 54(17):5988-5999. https://doi.org/10.1021/jm2003624

13. Labanauskas L, Udrenaite E, Gaidelis P, Brukstus A (2004) Synthesis of 5-(2-,3- and 4methoxyphenyl)-4H-1,2,4-triazole-3-thiol derivatives exhibiting anti-inflammatory activity. Farmaco 59(4):255-259. https://doi.org/10.1016/j.farmac.2003.11.002

14. Wang G, Peng Z, Wang J, Li X, Li J (2017) Synthesis, in vitro evaluation and molecular docking studies of novel triazine-triazole derivatives as potential alpha-glucosidase inhibitors. Eur J Med Chem 125:423-429. https://doi.org/1 0.1016/j.ejmech.2016.09.067

15. Al-Soud YA, Al-Dweri MN, Al-Masoudi NA (2004) Synthesis, antitumor and antiviral properties of some 1,2,4-triazole derivatives. Farmaco 59(10):775783. https://doi.org/10.1016/j.farmac.2004.05.006

16. Mathew V, Keshavayya J, Vaidya VP, Giles D (2007) Studies on synthesis and pharmacological activities of 3,6-disubstituted-1,2,4-triazolo[3,4-b]-1,3,4thiadiazoles and their dihydro analogues. Eur J Med Chem 42(6):823-840. https://doi.org/10.1016/j.ejmech.2006.12.010

17. Shaikh MH, Subhedar DD, Arkile M, Khedkar VM, Jadhav N, Sarkar D, Shingate BB (2016) Synthesis and bioactivity of novel triazole incorporated benzothiazinone derivatives as antitubercular and antioxidant agent. Bioorg Med Chem Lett 26(2):561-569. https://doi.org/10.1016/j.bmcl.2015.11.071

18. Khan I, Ali S, Hameed S, Rama NH, Hussain MT, Wadood A, Uddin R, UI-Haq Z, Khan A, Ali S, Choudhary MI (2010) Synthesis, antioxidant activities and urease inhibition of some new 1,2,4-triazole and 1,3,4-thiadiazole derivatives. Eur J Med Chem 45(11):5200-5207. https://doi.org/10.1016/j.ejmech.2010.08.034

19. Manohar S, Khan SI, Rawat DS (2011) Synthesis of 4-aminoquinoline-1,2,3triazole and 4-aminoquinoline-1,2,3-triazole-1,3,5-triazine hybrids as potential antimalarial agents. Chem Biol Drug Des 78(1):124-136. https://doi.org/1 0.1111/j.1747-0285.2011.01115.x

20. Chu XM, Wang C, Wang WL, Liang LL, Liu W, Gong KK, Sun KL (2019) Triazole derivatives and their antiplasmodial and antimalarial activities. Eur J Med Chem 166:206-223. https://doi.org/10.1016/j.ejmech.2019.01.047

21. Yang L, Wu Y, Yang Y, Wen C, Wan JP (2018) Catalyst-free synthesis of 4acyl-NH-1,2,3-triazoles by water-mediated cycloaddition reactions of enaminones and tosyl azide. Beilstein J Org Chem 14:2348-2353. https://doi. org/10.3762/bjoc.14.210

22. Shelke GM, Rao VK, Jha M, Cameron TS, Kumar A (2015) Microwave-assisted catalyst-free synthesis of substituted 1, 2, 4-triazoles. J Synlett 26:404-407

23. Bechara WS, Khazhieva IS, Rodriguez E, Charette AB (2015) One-pot synthesis of 3,4,5-trisubstituted 1,2,4-triazoles via the addition of hydrazides to activated secondary amides. Org Lett 17(5):1184-1187. https://doi.org/1 0.1021 /acs.orglett.5b00128

24. Yin $P$, Ma WB, Chen $Y$, Huang WC, Deng $Y$, He L (2009) Highly efficient cyanoimidation of aldehydes. Org Lett 11(23):5482-5485. https://doi.org/1 0.1021/ol902207h

25. Feldman AK, Colasson B, Fokin W (2004) One-pot synthesis of 1,4disubstituted 1,2,3-triazoles from in situ generated azides. Org Lett 6(22): 3897-3899. https://doi.org/10.1021/ol048859z

26. Chen Z, Li H, Dong W, Miao M, Ren H (2016) I2-catalyzed oxidative coupling reactions of hydrazones and amines and the application in the synthesis of 1,3,5-trisubstituted 1,2,4-triazoles. Org Lett 18(6):1334-1337. https://doi.org/1 0.1021 /acs.orglett.6b00277

27. Paneth A, Trotsko N, Popiolek L, Grzegorczyk A, Krzanowski T, Janowska S, Malm A, Wujec M (2019) Synthesis and antibacterial evaluation of Mannich bases derived from 1,2,4-triazole. Chem Biodivers 16:e1900377

28. Lipeeva AV, Zakharov DO, Burova LG, Frolova TS, Baev DS, Shirokikh IV, Evstropov AN, Sinitsyna Ol, Tolsikova TG, Shults EE (2019) Design, synthesis and antibacterial activity of coumarin-1,2,3-triazole hybrids obtained from natural furocoumarin peucedanin. Molecules 24(11):2126-2149. https://doi. org/10.3390/molecules 24112126

29. Tang KW, Yang SC, Tseng CH (2019) Design, synthesis, and anti-bacterial evaluation of triazolyl-pterostilbene derivatives. Int J Mol Sci 20(18):45644581. https://doi.org/10.3390/ijms20184564

30. Ni T, Pang L, Cai Z, Xie F, Ding Z, Hao Y, Li R, Yu S, Chai X, Wang T, Jin Y (2019) Design, synthesis, and in vitro antifungal evaluation of novel triazole derivatives bearing alkynyl side chains. J Saudi Chem Soc 23(5):576-585. https://doi.org/10.1016/j.jscs.2018.10.003

31. Yang L, Ge S, Huang J, Bao X (2018) Synthesis of novel (E)-2-(4-(1H-1,2,4triazol-1-yl)styryl)-4-(alkyl/arylmethyleneoxy)quinazoline derivatives as antimicrobial agents. Mol Divers 22:71-82. https://doi.org/10.1007/s11030-01 7-9792-1

32. Rezki N, Al-Yahyawi AM, Bardaweel SK, Al-Blewi FF, Aouad MR (2015) Synthesis of novel 2,5-disubstituted-1,3,4-thiadiazoles clubbed 1,2,4-triazole, 1,3,4-thiadiazole, 1,3,4-oxadiazole and/or Schiff base as potential antimicrobial and antiproliferative agents. Molecules 20(9):16048-16067. https://doi.org/10.3390/molecules200916048

33. Onkol T, Dogruer DS, Uzun L, Adak S, Ozkan S, Sahin MF (2008) Synthesis and antimicrobial activity of new 1,2,4-triazole and 1,3,4-thiadiazole derivatives. J Enzyme Inhib Med Chem 23(2):277-284. https://doi.org/10.1 080/14756360701408697

34. Turan-Zitouni G, Kaplancikli ZA, Yildiz MT, Chevallet P, Kaya D (2005) Synthesis and antimicrobial activity of 4-phenyl/cyclohexyl-5-(1phenoxyethyl)-3-[N-(2-thiazolyl)acetamido]thio-4H-1,2,4- triazole derivatives. Eur J Med Chem 40(6):607-613. https://doi.org/10.1016/j.ejmech.2005.01.007

35. Hussain M, Qadri T, Hussain Z, Saeed A, Channar PA, Shehzadi SA, Hassan M, Larik FA, Mahmood T, Malik A (2019) Synthesis, antibacterial activity and molecular docking study of vanillin derived 1,4-disubstituted 1,2,3-triazoles as inhibitors of bacterial DNA synthesis. Heliyon 5(11):e02812. https://doi. org/10.1016/j.heliyon.2019.e02812

36. Han X, Wang S, Zhang N, Ren L, Sun X, Song Y, Wang J, Xiao B (2020) Novel triazole derivatives containing different ester skeleton: design, synthesis, biological evaluation and molecular docking. Chem Pharm Bull (Tokyo) 68(1):64-69. https://doi.org/10.1248/cpb.c19-00624

37. Al-Blewi FF, Almehmadi MA, Aouad MR, Bardaweel SK, Sahu PK, Messali M, Rezki N, El Sayed H (2018) Design, synthesis, ADME prediction and pharmacological evaluation of novel benzimidazole-1, 2, 3-triazolesulfonamide hybrids as antimicrobial and antiproliferative agents. Chemistry Central Journal 12(1):110-124. https://doi.org/10.1186/s13065-018-0479-1

38. Ramprasad J, Sthalam VK, Thampunuri RLM, Bhukya S, Ummanni R, Balasubramanian S, Pabbaraja S (2019) Synthesis and evaluation of a novel quinoline-triazole analogs for antitubercular properties via molecular hybridization approach. Bioorganic Med Chem Letters 29(20):126671. https://doi.org/10.1016/j.bmcl.2019.126671

39. Ramprasad J, Nayak N, Dalimba U, Yogeeswari P, Sriram D (2015) One-pot synthesis of new triazole-Imidazo[2, 1-b][1, 3, 4]thiadiazole hybrids via click chemistry and evaluation of their antitubercular activity. Bioorganic medicinal chemistry letters 25(19):4169-4173. https://doi.org/10.1016/j. bmcl.2015.08.009

40. Raju KS, AnkiReddy S, Sabitha G, Krishna VS, Sriram D, Reddy KB, Sagurthi SR (2019) Synthesis and biological evaluation of $1 \mathrm{H}$-pyrrolo [2, 3-d] pyrimidine$1,2,3$-triazole derivatives as novel anti-tubercular agents. Bioorganic medicinal chemistry letters 29(2):284-290. https://doi.org/10.1016/j.bmcl.201 8.11 .036

41. Patel VM, Patel NB, Chan-Bacab MJ, Rivera G (2018) Synthesis, biological evaluation and molecular dynamics studies of 1,2,4-triazole clubbed Mannich bases. Comput Biol Chem 76:264-274. https://doi.org/10.1016/j. compbiolchem.2018.07.020

42. Ali AA, Gogoi D, Chaliha AK, Buragohain AK, Trivedi P, Saikia PJ, Gehlot PS, Kumar A, Chaturvedi V, Sarma D (2017) Synthesis and biological evaluation of novel 1, 2,3-triazole derivatives as anti-tubercular agents. Bioorg Med Chem Lett 27:3698-3703. 
43. Kharb R, Sharma PC, Bhandari A, Shaharyar M (2012) Synthesis, spectral characterization and anthelmintic evaluation of some novel imidazole bearing triazole derivatives. J Der Pharmacia Lettre 4:652-657

44. Satyendra RV, Vishnumurthy KA, Vagdevi HM, Rajesh KP, Manjunatha $H$, Shruthi A (2011) Synthesis, in vitro antioxidant, anthelmintic and molecular docking studies of novel dichloro substituted benzoxazole-triazolo-thione derivatives. Eur J Med Chem 46(7):3078-3084. https://doi.org/10.1016/j. ejmech.2011.03.017

45. Gupta JK, Mishra P (2017) Antimicrobial and anthelmintic activities of some newly synthesized triazoles. Asian J Pharm Clin Res 10(6):139-145. https:// doi.org/10.22159/ajpcr.2017.v10i6.17800

46. Verma KK, Singh UK, Jain J (2019) Design, synthesis and biological activity of some 4, 5-disubstituted-2, 4-dihydro-3H-1, 2, 4-triazole-3-thione derivatives. Cent Nerv Syst Agents Med Chem 19:197-205. https://doi.org/10.2174/1871 524919666190722144424

47. Wang S, Liu H, Wang X, Lei K, Li G, Li X, Wei L, Quan Z (2019) Synthesis and evaluation of anticonvulsant activities of 7-phenyl-4,5,6,7tetrahydrothieno[3,2-b ]pyridine derivatives. Arch Pharm (Weinheim) 352: e1900106

48. Zhang HJ, Shen QK, Jin CM, Quan ZS (2016) Synthesis and pharmacological evaluation of new 3,4-dihydroisoquinolin derivatives containing heterocycle as potential anticonvulsant agents. Molecules 21(12):1635-1652. https://doi. org/10.3390/molecules21121635

49. Mahdavi M, Akbarzadeh T, Sheibani V, Abbasi M, Firoozpour L, Tabatabai SA, Shafiee A, Foroumadi A (2010) Synthesis of two novel 3-amino-5-[4-chloro2-phenoxyphenyl]-4H-1,2,4-triazoles with anticonvulsant activity. Iran J Pharm Res 9(3):265-269

50. Song MX, Wang ZY, He SH, Yu SW, Chen SL, Guo DF, Zhao WH, Deng XQ (2018) Synthesis and evaluation of the anticonvulsant activities of 4-(2(alkylthio)benzo[d]oxazol-5-yl)-2,4-dihydro-3H-1,2,4-triazol-3-ones. Molecules 23(4):756-768. https://doi.org/10.3390/molecules23040756

51. Dehestani L, Ahangar N, Hashemi SM, Irannejad H, Honarchian Masihi $P$, Shakiba A, Emami S (2018) Design, synthesis, in vivo and in silico evaluation of phenacyl triazole hydrazones as new anticonvulsant agents. Bioorg Chem 78:119-129. https://doi.org/10.1016/j.bioorg.2018.03.001

52. Deng XQ, Quan LN, Song MX, Wei CX, Quan ZS (2011) Synthesis and anticonvulsant activity of 7-phenyl-6,7-dihydro-[1,2,4]triazolo[1,5-a]pyrimidin5(4H)-ones and their derivatives. Eur J Med Chem 46(7):2955-2963. https:// doi.org/10.1016/j.ejmech.2011.04.020

53. Siddiqui N, Ahsan W (2010) Triazole incorporated thiazoles as a new class of anticonvulsants: design, synthesis and in vivo screening. Eur J Med Chem 45(4):1536-1543. https://doi.org/10.1016/j.ejmech.2009.12.062

54. Zheng Y, Wang SB, Cao X, Liu DC, Shu B, Quan ZS (2014) Design, synthesis and anticonvulsant activity evaluation of novel 4-(4-substitutedphenyl)-3methyl-1H-1,2,4-triazol-5(4H)-ones. Drug Res (Stuttg) 64(1):40-46. https://doi. org/10.1055/s-0033-1351316

55. Tariq S, Alam O, Amir M (2018) Synthesis, anti-inflammatory, p38alpha MAP kinase inhibitory activities and molecular docking studies of quinoxaline derivatives containing triazole moiety. Bioorg Chem 76:343-358. https://doi. org/10.1016/j.bioorg.2017.12.003

56. Ahirwar J, Ahirwar D, Lanjhiyana S, Jha A, Dewangan D, Badwaik H (2018) Analgesic and anti-inflammatory potential of merged pharmacophore containing 1, 2, 4-triazoles and substituted benzyl groups via thio linkage. Journal of Heterocyclic Chemistry 55(9):2130-2141. https://doi.org/10.1002/ jhet. 3258

57. Khan SA, Imam SM, Ahmad A, Basha SH, Husain A (2018) Synthesis, molecular docking with COX $1 \& \|$ enzyme, ADMET screening and in vivo anti-inflammatory activity of oxadiazole, thiadiazole and triazole analogs of felbinac. Journal of Saudi Chemical Society 22(4):469-484. https://doi.org/1 0.1016/j.jscs.2017.05.006

58. Zhang HJ, Wang XZ, Cao Q, Gong GH, Quan ZS (2017) Design, synthesis, anti-inflammatory activity, and molecular docking studies of perimidine derivatives containing triazole. Bioorg Med Chem Lett 27(18):4409-4414. https://doi.org/10.1016/j.bmcl.2017.08.014

59. Sarigol D, Uzgoren-Baran A, Tel BC, Somuncuoglu El, Kazkayasi I, Ozadali-Sari K, Unsal-Tan O, Okay G, Ertan M, Tozkoparan B (2015) Novel thiazolo[3,2-b]-1,2,4 triazoles derived from naproxen with analgesic/anti-inflammatory properties: Synthesis, biological evaluation and molecular modeling studies. Bioorg Med Chem 23(10):2518-2528. https://doi.org/10.1016/j.bmc.2015.03.049

60. Almasirad A, Shafiee A, Abdollahi M, Noeparast A, Shahrokhinejad N, Vousooghi N, Tabatabai SA, Khorasani R (2011) Synthesis and analgesic activity of new 1, 3, 4-oxadiazoles and 1, 2, 4-triazoles. Medicinal Chemistry Research 20(4):435-442. https://doi.org/10.1007/s00044-010-9335-0

61. Haider S, Alam MS, Hamid H, Shafi S, Nargotra A, Mahajan P, Nazreen S, Kalle AM, Kharbanda C, Ali Y, Alam A (2013) Synthesis of novel 1,2,3-triazole based benzoxazolinones: their TNF-alpha based molecular docking with invivo anti-inflammatory, antinociceptive activities and ulcerogenic risk evaluation. Eur J Med Chem 70:579-588. https://doi.org/10.1016/j.ejmech.2 013.10 .032

62. Shafi S, Alam MM, Mulakayala N, Mulakayala C, Vanaja G, Kalle AM, Pallu R, Alam MS (2012) Synthesis of novel 2-mercapto benzothiazole and 1,2,3triazole based bis-heterocycles: their anti-inflammatory and anti-nociceptive activities. Eur J Med Chem 49:324-333. https://doi.org/10.1016/j.ejmech.2 012.01.032

63. Abuo-Rahma Gel D, Abdel-Aziz M, Farag NA, Kaoud TS (2014) Novel 1-[4(aminosulfonyl)phenyl]-1H-1,2,4-triazole derivatives with remarkable selective COX-2 inhibition: design, synthesis, molecular docking, anti-inflammatory and ulcerogenicity studies. Eur J Med Chem 83:398-408. https://doi.org/10.1 016/j.ejmech.2014.06.049

64. Tozkoparan B, Kupeli E, Yesilada E, Ertan M (2007) Preparation of 5-aryl-3alkylthio-1,2,4-triazoles and corresponding sulfones with antiinflammatoryanalgesic activity. Bioorg Med Chem 15(4):1808-1814. https://doi.org/10.101 6/j.bmc.2006.11.029

65. Kaur J, Bhardwaj A, Sharma SK, Wuest F (2013) 1,4-Diaryl-substituted triazoles as cyclooxygenase-2 inhibitors: synthesis, biological evaluation and molecular modeling studies. Bioorg Med Chem 21(14):4288-4295. https:// doi.org/10.1016/j.bmc.2013.04.074

66. Mahanti S, Sunkara S, Bhavani R (2019) Synthesis, biological evaluation and computational studies of fused acridine containing 1, 2, 4-triazole derivatives as anticancer agents. Synthetic Communications 49(13):17291740. https://doi.org/10.1080/00397911.2019.1608450

67. Al-Wahaibi LH, Abu-Melha HM, Ibrahim DA (2018) Synthesis of novel 1, 2, 4triazolyl coumarin derivatives as potential anticancer agents. J Chem 5201374:1-8

68. Ma LY, Pang LP, Wang B, Zhang M, Hu B, Xue DQ, Shao KP, Zhang BL, Liu Y, Zhang E, Liu HM (2014) Design and synthesis of novel 1,2,3-triazolepyrimidine hybrids as potential anticancer agents. Eur J Med Chem 86:368380. https://doi.org/10.1016/j.ejmech.2014.08.010

69. Duan YC, Ma YC, Zhang E, Shi XJ, Wang MM, Ye XW, Liu HM (2013) Design and synthesis of novel 1,2,3-triazole-dithiocarbamate hybrids as potential anticancer agents. Eur J Med Chem 62:11-19. https://doi.org/10.1016/j. ejmech.2012.12.046

70. Aouad MR, Soliman MA, Alharbi MO, Bardaweel SK, Sahu PK, Ali AA, Messali M, Rezki N, Al-Soud YA (2018) Design, synthesis and anticancer screening of novel benzothiazole-piperazine-1,2,3-triazole hybrids. Molecules 23(11):27882802. https://doi.org/10.3390/molecules23112788

71. Ashwini N, Garg M, Mohan CD, Fuchs JE, Rangappa S, Anusha S, Swaroop TR, Rakesh KS, Kanojia D, Madan V, Bender A (2015) Synthesis of 1,2benzisoxazole tethered 1,2,3-triazoles that exhibit anticancer activity in acute myeloid leukemia cell lines by inhibiting histone deacetylases, and inducing p21 and tubulin acetylation. Bioorg Med Chem 23(18):6157-6165. https://doi.org/10.1016/j.bmc.2015.07.069

72. Dhawan S, Awolade P, Kisten P, Cele N, Pillay AS, Saha S, Kaur M, Jonnalagadda SB, Singh P (2020) Synthesis, cytotoxicity and antimicrobial evaluation of new coumarin-tagged beta-lactam triazole hybrid. Chem Biodivers 17:e1900462

73. Saftic D, Zinic B, Glavas-Obrovac L, Studzinska M, Paradowska E, Lesnikowski $\mathrm{ZJ}$ (2018) Synthesis and in vitro evaluation of antiviral and cytostatic properties of novel 8-triazolyl acyclovir derivatives. Nucleosides Nucleotides Nucleic Acids 37(7):397-414. https://doi.org/10.1080/15257770.2018.1485932

74. Saeedi M, Mohammadi-Khanaposhtani M, Pourrabia P, Razzaghi N, Ghadimi R, Imanparast S, Faramarzi MA, Bandarian F, Esfahani EN, Safavi M, Rastegar $H$ (2019) Design and synthesis of novel quinazolinone-1,2,3-triazole hybrids as new anti-diabetic agents: in vitro alpha-glucosidase inhibition, kinetic, and docking study. Bioorg Chem 83:161-169. https://doi.org/10.1016/j. bioorg.2018.10.023

75. Avula SK, Khan A, Rehman NU, Anwar MU, Al-Abri Z, Wadood A, Riaz M, Csuk R, Al-Harrasi A (2018) Synthesis of 1H-1,2,3-triazole derivatives as new alpha-glucosidase inhibitors and their molecular docking studies. Bioorg Chem 81:98-106. https://doi.org/10.1016/j.bioorg.2018.08.008

76. Chinthala $Y$, Thakur S, Tirunagari S, Chinde S, Domatti AK, Arigari NK, Srinivas KV, Alam S, Jonnala KK, Khan F, Tiwari A (2015) Synthesis, docking and 
ADMET studies of novel chalcone triazoles for anti-cancer and anti-diabetic activity. Eur J Med Chem 93:564-573. https://doi.org/10.1016/j.ejmech.2015. 02.027

77. Gonzaga D, Senger MR, Da Silva FC, Ferreira VF, Silva-Jr FP (2014) 1-Phenyl$1 \mathrm{H}$-and 2-phenyl-2H-1, 2, 3-triazol derivatives: design, synthesis and inhibitory effect on alpha-glycosidases. European Journal of Medicinal Chemistry 74:461-476. https://doi.org/10.1016/j.ejmech.2013.12.039

78. Ju H, Xiu S, Ding X, Shang M, Jia R, Huang B, Zhan P, Liu X (2020) Discovery of novel 1,2,3-triazole oseltamivir derivatives as potent influenza neuraminidase inhibitors targeting the 430-cavity. Eur J Med Chem 187: 111940. https://doi.org/10.1016/j.ejmech.2019.111940

79. Jordao AK, Afonso PP, Ferreira VF, de Souza MC, Almeida MC, Beltrame CO, Paiva DP, Wardell SM, Wardell JL, Tiekink ER, Damaso CR (2009) Antiviral evaluation of $\mathrm{N}$-amino-1,2,3-triazoles against Cantagalo virus replication in cell culture. Eur J Med Chem 44(9):3777-3783. https://doi.org/10.1016/j. ejmech.2009.04.046

80. Kucukguzel I, Tatar E, Kucukguzel SG, Rollas S, De Clerca E (2008) Synthesis of some novel thiourea derivatives obtained from $5-[(4-$ aminophenoxy)methyll-4-alkyl/aryl-2,4-dihydro-3H-1,2,4-triazole-3-thiones and evaluation as antiviral/anti-HIV and anti-tuberculosis agents. Eur J Med Chem 43(2):381-392. https://doi.org/10.1016/.ejmech.2007.04.010

81. Wang Z, Wu B, Kuhen KL, Bursulaya B, Nguyen TN, Nguyen DG, He Y (2006) Synthesis and biological evaluations of sulfanyltriazoles as novel HIV-1 nonnucleoside reverse transcriptase inhibitors. Bioorg Med Chem Lett 16(16): 4174-4177. https://doi.org/10.1016/j.bmcl.2006.05.096

82. Karypidou K, Ribone SR, Quevedo MA, Persoons L, Pannecouque C, Helsen C, Claessens F, Dehaen W (2018) Synthesis, biological evaluation and molecular modeling of a novel series of fused 1,2,3-triazoles as potential anti-coronavirus agents. Bioorg Med Chem Lett 28(21):3472-3476. https:// doi.org/10.1016/j.bmcl.2018.09.019

83. Cao X, Wang W, Wang S, Bao L (2017) Asymmetric synthesis of novel triazole derivatives and their in vitro antiviral activity and mechanism of action. European Journal of Medicinal Chemistry 139:718-725. https://doi. org/10.1016/j.jmech.2017.08.057

84. Mohammed I, Kummetha IR, Singh G, Sharova N, Lichinchi G, Dang J, Stevenson M, Rana TM (2016) 1,2,3-Triazoles as amide bioisosteres: discovery of a new class of potent HIV-1 Vif antagonists. J Med Chem 59(16):76777682. https://doi.org/10.1021/acs.jmedchem.6b00247

85. Oramas-Royo S, Lopez-Rojas P, Amesty A, Gutierrez D, Flores N, MartinRodriguez P. Fernández-Pérez L, Estévez-Braun A (2019) Synthesis and antiplasmodial activity of 1,2,3-triazole-naphthoquinone conjugates. Molecules 24(21):3917-3939. https://doi.org/10.3390/molecules24213917

86. Thakur RK, Joshi P, Baranwal P, Sharma G, Shukla SK, Tripathi R, Tripathi RP (2018) Synthesis and antiplasmodial activity of glyco-conjugate hybrids of phenylhydrazono-indolinones and glycosylated 1,2,3-triazolyl-methylindoline-2,3-diones. Eur J Med Chem 155:764-771. https://doi.org/10.1016/j. ejmech.2018.06.042

87. Thakkar SS, Thakor P, Doshi H, Ray A (2017) 1,2,4-Triazole and 1,3,4oxadiazole analogues: synthesis, MO studies, in silico molecular docking studies, antimalarial as DHFR inhibitor and antimicrobial activities. Bioorg Med Chem 25(15):4064-4075. https://doi.org/10.1016/j.bmc.2017.05.054

88. Joshi MC, Wicht KJ, Taylor D, Hunter R, Smith PJ, Egan TJ (2013) In vitro antimalarial activity, beta-haematin inhibition and structure-activity relationships in a series of quinoline triazoles. Eur J Med Chem 69:338-347. https://doi.org/10.1016/j.ejmech.2013.08.046

89. Guantai EM, Ncokazi K, Egan TJ, Gut J, Rosenthal PJ, Smith PJ, Chibale K (2010) Design, synthesis and in vitro antimalarial evaluation of triazole-linked chalcone and dienone hybrid compounds. Bioorg Med Chem 18(23):82438256. https://doi.org/10.1016/j.bmc.2010.10.009

90. Tarawneh AH, Al-Momani LAA, Leon F, Jain SK, Gadetskaya AV, Abu-Orabi ST, Tekwani BL, Cutler SJ (2018) Evaluation of triazole and isoxazole derivatives as potential anti-infective agents. Med Chem Res 27(4):12691275. https://doi.org/10.1007/s00044-018-2146-4

91. Li JC, Zhang J, Rodrigues MC, Ding DJ, Longo JP, Azevedo RB, Muehlmann LA, Jiang CS (2016) Synthesis and evaluation of novel 1,2,3-triazole-based acetylcholinesterase inhibitors with neuroprotective activity. Bioorg Med Chem Lett 26(16):3881-3885. https://doi.org/10.1016/j.bmcl.2016.07.017

92. Liu J, Liu Q, Yang X, Xu S, Zhang H, Bai R, Yao H, Jiang J, Shen M, Wu X, Xu $J$ (2013) Design, synthesis, and biological evaluation of 1,2,4-triazole bearing 5 -substituted biphenyl-2-sulfonamide derivatives as potential antihypertensive candidates. Bioorg Med Chem 21(24):7742-7751. https:// doi.org/10.1016/j.bmc.2013.10.017

93. Nair N, Kudo W, Smith MA, Abrol R, Goddard WA, Reddy VP (2011) Novel purine-based fluoroaryl-1,2,3-triazoles as neuroprotecting agents: synthesis, neuronal cell culture investigations, and CDK5 docking studies. Bioorg Med Chem Lett 21(13):3957-3961. https://doi.org/10.1016/j.bmcl.2011.05.019

94. Girmenia C (2009) New generation azole antifungals in clinical investigation. Expert Opin Investig Drugs 18(9):1279-1295. https://doi.org/10.1517/13543 780903176407

95. Smith J, Safdar N, Knasinski V, Simmons W, Bhavnani SM, Ambrose PG, Andes D (2006) Voriconazole therapeutic drug monitoring. Antimicrob Agents Chemother 50(4):1570-1572. https://doi.org/10.1128/AAC.50.4.1570-1 572.2006

96. Giordano SH, Valero V, Buzdar AU, Hortobagyi GN (2002) Efficacy of anastrozole in male breast cancer. Am J Clin Oncol 25(3):235-237. https:// doi.org/10.1097/00000421-200206000-00006

97. Wingrove PB, Wafford KA, Bain C, Whiting PJ (1994) The modulatory action of loreclezole at the gamma-aminobutyric acid type A receptor is determined by a single amino acid in the beta 2 and beta 3 subunit. Proc Natl Acad Sci U S A 91(10):4569-4573. https://doi.org/10.1073/pnas.91.10.4569

98. Millson DS, Tepper SJ, Rapoport AM (2000) Migraine pharmacotherapy with oral triptans: a rational approach to clinical management. Expert Opin Pharmacother 1(3):391-404. https://doi.org/10.1517/14656566.1.3.391

99. Goss PE (1998) Pre-clinical and clinical review of vorozole, a new third generation aromatase inhibitor. Breast Cancer Res Treat 49:59-65

100. Crotty S, Cameron C, Andino R (2002) Ribavirin's antiviral mechanism of action: lethal mutagenesis? J Mol Med (Berl) 80(2):86-95. https://doi.org/10.1 007/s00109-001-0308-0

101. Alvarez D, Dieterich DT, Brau N, Moorehead L, Ball L, Sulkowski MS (2006) Zidovudine use but not weight-based ribavirin dosing impacts anaemia during HCV treatment in HIV-infected persons. J Viral Hepat 13(10):683-689. https://doi.org/10.1111/j.1365-2893.2006.00749.x

102. Miura M, Otani K, Ohkubo T (2005) Identification of human cytochrome P450 enzymes involved in the formation of 4-hydroxyestazolam from estazolam. Xenobiotica 35(5):455-465. https://doi.org/10.1080/004982 50500111612

103. Borras L, de Timary P, Constant EL, Huquelet P, Eytan A (2006) Successful treatment of alcohol withdrawal with trazodone. Pharmacopsychiatry 39(6): 232. https://doi.org/10.1055/s-2006-951385

104. Bechir M, Schwegler K, Chenevard R, Binggeli C, Caduff C, Buchi S, Buddeberg C, Lüscher TF, Noll G (2007) Anxiolytic therapy with alprazolam increases muscle sympathetic activity in patients with panic disorders. Auton Neurosci 134(1-2):69-73. https://doi.org/10.1016/j.autneu.2007.01.007

105. Wolf BC, Lavezzi WA, Sullivan LM, Middleberg RA, Flannagan LM (2005) Alprazolam-related deaths in Palm Beach County. Am J Forensic Med Pathol 26(1):24-27. https://doi.org/10.1097/01.paf.0000153994.95642.c1

\section{Publisher's Note}

Springer Nature remains neutral with regard to jurisdictional claims in published maps and institutional affiliations.

\section{Submit your manuscript to a SpringerOpen ${ }^{\circ}$ journal and benefit from:}

- Convenient online submission

- Rigorous peer review

- Open access: articles freely available online

- High visibility within the field

- Retaining the copyright to your article

Submit your next manuscript at $\boldsymbol{\nabla}$ springeropen.com 